\title{
MELETIUS OU CARTA SOBRE AQUILO QUE É OBJETO DE ACORDO ENTRE OS CRISTÃOS ${ }^{1}$
}

\author{
Hugo Grotius \\ Tradução por Weslin de Jesus Santos Castro \\ Aliança Francesa de Aracaju (AF/Aracaju) \\ (i) https://orcid.org/0000-0003-0382-1173 \\ Revisão por Dominique Marie Phillipe Geneviève Boxus \\ Universidade Federal Fluminense (UFF)
}

Muitas vezes, meu ilustre amigo, eu me lembro, dentre tantas lições úteis, ter ouvido você evocar esta excelente lembrança do tempo em que você passava uma estada nos confins da Ásia, motivado pelo desejo de aprender, lá onde outros buscam apenas lucro. Quando você encontrava alguém vindo das nossas regiões da Europa, você o tratava como um concidadão, ou melhor, como um parente. A bondade de sua natureza e a preocupação com a humanidade lhe incitavam a isso. Mas, no mais, é crível que isso se dê com outros, pois a dificuldade e a raridade dos contatos e todo esse contexto estrangeiro favorecem esses tipos de encontro que, ordinariamente, se desfazem e perecem em meio à multidão. Assim, nós que vivemos aqui, não consideramos apenas como estrangeiros os outros europeus, mas distinguimos entre os alemães, os Alto-Alemães dos BaixoAlemães. Os Baixo-Alemães estão divididos pela lembrança de uma guerra apenas pacificada ${ }^{2}$; distinguem-se em seguida os Gueldres ${ }^{3}$ dos Frisões ${ }^{4}$, sem falar das pessoas da Holanda e da Zelândia que formaram sempre nações estreitamente unidas. Que eles possam diferir apenas no nome, e não no coração. Eu passo sobre as rivalidades entre as cidades - e nestas os conflitos de bairros - e às rivalidades entre as grandes famílias. Ao analisar bem isso, constata-se que vizinhos e próximos se consideram muito mais

\footnotetext{
${ }^{1}$ Esta tradução em língua portuguesa decorre de uma tradução em língua francesa que se apoia na edição crítica do texto latino de Hugo Grotius, Meletius sive De iis inter Christianos conveniunt Epistola, feita por Guillaume H. M. Posthumus Meyjes e publicada com uma tradução em língua inglesa de E.J. Brill, Leiden-Nova York, em 1988. O referido texto constitui o objeto de estudo do livro La raison ardente: religion naturelle et raison au XVII ${ }^{\text {ème }}$ siècle (A razão ardente: religião natural e razão no século XVII).

${ }^{2}$ Referência à guerra com a Espanha, interrompida pela Treva de 12 anos de 1609 a 1621 .

${ }^{3}$ Província dos Países-Baixos.

${ }^{4}$ Habitantes da Frísia, província dos Países-Baixos que faz fronteira com a Alemanha.
} 
como estrangeiros do que os próprios Italianos ou Espanhóis o eram para você quando estava na Síria.

A meu ver, aconteceu a mesma coisa com a religião. Desde que o nome de cristão se expandiu largamente e a força dos seus inimigos foi quebrada, houve espaço livre para dissensões, de opinião primeiramente e logo depois de sentimento; denominações e maneiras de pensar diversas surgiram e tornaram os Cristãos tão estrangeiros para os cristãos que eles não foram mais cristãos uns com os outros. Essa doença se declarou outrora, mas no tempo dos nossos pais e no nosso, ela se agravou ao ponto de não poder estender-se em mais alto grau. Não apenas o esfriamento dos corações e a rivalidade, mas também o ódio e a cólera implacável, e, fato quase sem precedentes, guerras nasceram sob o único pretexto desta religião que propõe a paz. Mas, se nós quisermos levar em consideração esses Indianos ${ }^{5}$ - a quem nos conduzem nossos sucessos de navegação - ou os Turcos com os quais você vive, ou os Judeus ${ }^{6}$ que vivem doravante entre nós, poderemos nos perguntar: como não nos uniria aquilo que nos afasta deles, tomados separadamente ou em bloco?

Se cada um reivindica para si a apelação de cristão excluindo os outros, que procuremos ao menos outro nome para nos distinguir todos juntos do paganismo daqueles que eu citei. Mas com certeza nós não encontraríamos outro além do que nos foi dado pelo Mestre, a quem todos nós prometemos obedecer, ainda que, por ignorância, não o façamos. Nada pode ser tão grande fator de discórdia que não seja superado por esse fator maior de concórdia, que o fato de seguir um mestre único, sobretudo aquele que reconhece como discípulos apenas os que cultivam a concórdia. Por isso, de encontro às novas dissensões de hoje e a outras perturbações renascentes, eu tenho o costume de me consolar e de me reconfortar com o pensamento daquilo que, pela benevolência de Deus, permaneceu preservado ate hoje entre os cristãos. Coisas muito importantes, muito certas e muito úteis, e cujo valor é tão maior aos meus olhos que ao considerá-las, eu as separo de outras menos importantes, menos certas e menos úteis. Que esses privilégios, por assim dizer, nos conduzam a sermos cidadãos de uma única cidade.

Como eu gostaria que me fosse possível discutir essas coisas com você, como era tão frequente outrora, quando estávamos juntos! Com quem então eu falaria sobre isso mais abertamente do que com um dos raros a ter mostrado que a verdadeira jurisprudência não abrange apenas o

\footnotetext{
${ }^{5}$ Cf. O desenvolvimento da Companhia das Índias Orientais e o tratado de Grotius: Mare liberum sive de jure quod batavis competit ad Indicana commercia dissertatio que data de 1609. (tradução francesa, reimpressa em Caen, 1990)

${ }^{6}$ Alusão aos três grandes grupos religiosos a serem convertidos: os pagãos, os muçulmanos, e os judeus. Cf. VRC, IV: refutação do paganismo; V: refutação do judaísmo; VI: refutação do maometanismo.

Hugo Grotius - Meletius ou carta sobre aquilo que é objeto de acordo entre os cristãos. Tradução por Weslin de Jesus Santos Castro. Revisão por Dominique Marie Phillipe Geneviève Boxus
} 
conhecimento das coisas humanas, mas ainda o das coisas divinas ${ }^{7}$, alguém que conhece muito bem os inimigos do cristianismo, antigos e modernos, alguém tão bem instruído nas letras gregas e hebraicas, e que perfeitamente estudou muito as seitas dos cristãos, não apenas aquelas nas quais estamos divididos hoje, mas também os Gregos, os Armênios e os Maronitas. Quando você vivia entre eles, você nunca deixou de lhes parecer cristãos - e eles também para você, apesar de que sobre muitos pontos, as suas teses fossem mais justas do que as deles.

Mas, uma vez que o distanciamento e a necessidade de nossos cargos não nos permitem ficar juntos, eu deixarei por escrito o que o patriarca Meletius tinha o costume de expor, como você dizia, mas, sob a condição de que você, que conhece melhor tudo isso, modifique-o para corrigir. E não duvido disso, ser-lhe-á doce trazê-lo de volta à memória, e para mim vantajoso aprendê-lo de você mais perfeitamente. Assim então, Meletius era patriarca de Alexandria e dirigia também a igreja de Constantinopla; era um homem de uma santidade venerável e naturalmente versado em todo tipo de erudição - ele falava latim, o que não era comum entre os gregos, e ele lera todos os autores célebres desta língua. Ele amava ao mais alto grau a paz cristã, acometia-lhe frequentemente chorar nossas dissensões - que ele execrava - e suplicar para que dirigíssemos enfim nossos olhos (tornados selvagens de tanto olhar para nós) mais para os Turcos e para o pântano dos povos bárbaros. Ele insistia, sobretudo, nos pontos em que os cristãos convergiam $^{8}$. Eles são tão numerosos, dizia ele, e de importância tal que não se pensa neles ordinariamente; ele mostrava igualmente que havia nestes pontos de acordo tudo o que as escolas dos filósofos ou as instituições dos povos consideraram como excelentes, com pontos peculiares que os outros não tinham conhecido. Ele enfeitava isso com uma eloquência singular, e nós perseguíamos sua missão com todo o cuidado de que somos capazes.

O primeiro ponto que a cristandade divide com muitos, mas não com

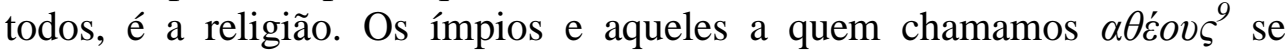
afastam desta fronteira. Não há religião sem estes dois pontos que o Apóstolo lembra na sua carta aos Hebreus ${ }^{10}$ : acreditar que Deus existe e que ele recompensa aqueles que se esforçam para Lhe agradar. A existência de Deus é comprovada muito claramente, não somente por um consenso

\footnotetext{
${ }^{7}$ A teoria da religião natural se encontra com efeito em DGP, II. ch. XX, § 40-48.

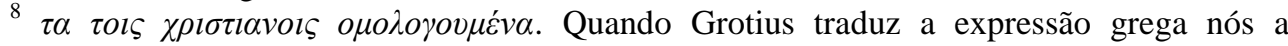
traduzimos no texto; quando ele escreve o grego sem traduzi-lo, nós reproduzimos o grego e damos a tradução em nota.

${ }^{9}$ Sem deuses ou ateus. A expressão é retomada de Cícero, DND, I, § 63: Digoras atheos qui dictus est.

${ }^{10}$ Cf. Annot. in NT sobre Heb. 11:6 onde Grotius reenvia a DGP, II, XX. 46. "Hae notiones numem aliquod esse (unum an plura sepono) et curare ab eo res hominum, maxime sunt universales et ad religionem sive veram sive falsam constituendam omnino necessariae."

Hugo Grotius - Meletius ou carta sobre aquilo que é objeto de acordo entre os cristãos. Tradução por Weslin de Jesus Santos Castro. Revisão por Dominique Marie Phillipe Geneviève Boxus
} 
largamente difundido entre os homens ${ }^{11}$, mas ainda pela ordem de dependência mútua das causas e pela hierarquia dos seres ${ }^{12}$. Essa verdade é tão evidente que em muitos séculos pouquíssimas pessoas ousaram dizer outra coisa, e provavelmente porque elas preferiam que não fosse assim mais do que porque o pensavam verdadeiramente. ${ }^{13}$

Para que Deus recompense, é necessário admitir previamente alguns pontos. É preciso em primeiro lugar que Deus seja uma natureza inteligente: isso é suficientemente provado, a partir do fato de que é impossível que aquilo que é feito seja mais nobre do que aquele que o fez. Deus não é o mundo ou aquilo que chamamos ordinariamente de natureza, mas algo mais elevado e mais venerável. Deus não deve ter apenas inteligência, mas também vontade e aquilo que se chama $\pi \rho o \alpha i \rho \varepsilon \sigma l v^{14}$, pois aqueles que a têm são mais perfeitos do que aqueles que não a têm. E esta vontade própria deve ser livre e não impedida, pois isso pertence à perfeição, e é impossível por natureza que alguma outra causa seja superior à causa suprema. Este argumento refuta os Estoicos ${ }^{15}$, que num abuso totalmente estúpido submetem Deus à necessidade do destino. Daí, eis um verso ímpio ${ }^{16}$ : "Aquilo que foi decretado pelo destino supera o poder do grande Júpiter".

Com o mesmo argumento refuta-se outro erro, também muito grande, dos antigos Magos que afirmavam que Deus podia ser contido em fórmulas solenes, ou em outras coisas que $\mathrm{O}$ põem em discurso para negá-lo em fato.

É preciso admitir também que Deus cuida daquilo que Ele fez, não apenas das realidades celestes, mas também das humanas; com esta tese rejeitamos os Epicureus, que não teriam errado se eles tivessem dito que Deus supervisiona e rege todas as coisas sem cuidado. Mas eles se enganaram horrivelmente pensando que usar o entendimento e a vontade é um cuidado, ao passo que nada é mais doce, sobretudo, com toda onipotência. As dificuldades a serem conduzidas pertencem à fraqueza daqueles que a dirigem. Muito cruéis são os pais que abandonam com satisfação os filhos que eles geraram. Se Deus não é bom, ele não é Deus. Acrescentemos que a ordem admirável do universo não fala apenas de Deus como criador, mas também como regente. Nada é menos conforme a realeza do que tomar conta das partes mais vis do reino e não se importar com as partes mais nobres.

\footnotetext{
${ }^{11}$ VRC I, 2 \& I, 7.

${ }^{12}$ Tema estoico e neoplatônico.

${ }^{13}$ Cicero DND I, 63 e Lactancio ID, I, 2, § 1.

${ }^{14}$ Designa em Aristóteles (E. N. III, 5) a escolha refletida, precedida de deliberação.

${ }^{15}$ SVF. II, 912.

${ }^{16}$ Citado e traduzido do grego por Cícero, Div. II, 10; origem desconhecida.

Hugo Grotius - Meletius ou carta sobre aquilo que é objeto de acordo entre os cristãos. Tradução por Weslin de Jesus Santos Castro. Revisão por Dominique Marie Phillipe Geneviève Boxus
} 
Mas para que haja recompensa, é preciso admitir que o homem é

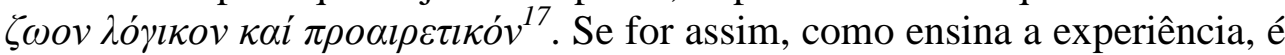
necessário suprimir o destino dos estoicos. Pois, se todo o futuro depende de causas necessárias, é em vão que o homem teria recebido esse poder de deliberação e a vontade de escolher entre os contrários ${ }^{18}$. Mas sustentar que alguma coisa existe em vão na natureza, e, sobretudo no homem, é taxar de imperícia o autor da natureza.

Segue-se que nós reconhecemos Deus por legislador. Pois se Deus dispõe de escolha refletida ${ }^{19}$, o homem também dispõe. Ora, Deus é superior e o homem é inferior. O superior age sobre o inferior porque a natureza do superior é agir, e a do inferior é sofrer. Disso resulta que Deus age sobre o homem segundo uma escolha refletida ${ }^{20}$. Mas esta ação da escolha refletida $^{21}$ do superior sobre a escolha refletida ${ }^{22}$ do inferior não é outra coisa senão a lei ou o mandamento. A consciência íntima nos convence da verdade sobre isso mais fortemente do que todas as outras provas.

Tendo posto isso, estabelecemos facilmente o que concerne à remuneração. É justo recompensar aquele que respeita à lei e punir aquele que a viola. Ora, Deus é justo e age com justiça. Todo legislador deseja que suas leis sejam respeitadas. Ele emprega então para esse fim todos os meios de que ele dispõe. Ora, não há nada mais estimulante à obediência que a recompensa. Deus pode recompensar, o que os legisladores humanos não o podem fazer sempre. Deus recompensa então.

Eis então os princípios que a religião crista partilha com todas as outras, com as falsas e com as verdadeiras que são menos perfeitas, em primeiro lugar com a religião natural, depois com a religião mosaica. Sobre quem suprime estes pontos, pode-se dizer verdadeiramente que suprime a religião, a coisa mais importante do mundo. O que há de melhor ou mais útil, além disso: tudo aquilo que é moralmente bom e reto pode ser objeto não apenas das ações, mas também dos pensamentos humanos? As leis humanas não podem garantir isso, pois não só nossos pensamentos, mas a maior parte dos nossos atos lhe escapa. Mas a religião pode garantir. Apenas ela pode. "E útil que existam deuses, e uma vez que é útil, admitamos que eles existem.”, como diz o poeta ${ }^{23}$. Nós dizemos mais verdadeiramente: é bom que a religião exista, logo, ela existe. Pois o dirigente mais eminentemente sábio não deixou de instituir tudo o que é eminentemente bom.

\footnotetext{
${ }^{17}$ Um animal dotado de razão e de escolha refletida. Fórmula que condensa duas definições aristotélicas: aquela de Polit, I, 2, 1253a e EN III,4.

${ }^{18}$ Vis deliberativa et voluntas in untrunque, e a tradução de proairesis.

${ }^{19} \pi \rho 0 \alpha i ́ \rho \varepsilon \sigma v$.

${ }^{20} \kappa \alpha \tau \alpha \pi \rho o \alpha i ́ \rho \varepsilon \sigma \mathrm{v}$.

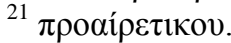

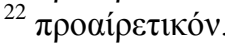

${ }^{23}$ Ovídio, Ars amandi, I, 637.

Hugo Grotius - Meletius ou carta sobre aquilo que é objeto de acordo entre os cristãos. Tradução por Weslin de Jesus Santos Castro. Revisão por Dominique Marie Phillipe Geneviève Boxus
} 


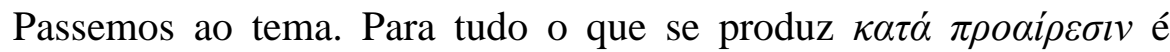
necessário procurar logo o fim. O fim daquilo que é mais excelente é o fim mais excelente. Mas a religião é a mais excelente de todas as coisas. O seu fim, logo, é simplesmente excelente, ou seja, é o supremo bem. Aquele que é o Supremo Bem ou a beatitude do homem foi por muito tempo objeto de grandes controvérsias entre filósofos. A religião cristã, tal como a reta razão, mostram que o Supremo Bem do homem é usufruir o mais perfeitamente daquele que é por si mesmo o Supremo Bem, ou seja, Deus.

Da mesma maneira que a natureza impassível nos ensina que há apenas uma causa eficiente do progresso infinito, da mesma maneira ela nos ensina que tudo está em vista e sob a causa de um único ser. Só podemos usufruir de Deus por meio daquilo que mais se aproxima dEle, a saber, o espírito. E uma vez que a beatitude concerne ao homem por inteiro e não em parte, segue-se que as outras partes da alma e do próprio corpo se tornam participantes desta beatitude, submetendo-se o mais perfeitamente ao espírito. Uma vez posto o bem em toda sua plenitude, todo mal e necessariamente suprimido. Logo, estarão ligadas a essa felicidade suprema a ausência de dor e a imortalidade.

Vê-se então que todos aqueles que procuraram o Supremo Bem do homem nesta vida frágil se enganaram. Há realmente algo que se pode chamar de o Supremo Bem nesta vida: começar a usufruir de Deus com a esperança certa de outra vida. Mas tomado simplesmente, esse bem não pode ser dito supremo, pois ele compreende também a espera da morte e a possibilidade da dor. Todos os filósofos se enganaram então, mesmo aqueles que - tese mais plausível que todas - procuraram o bem desta vida na virtude. Logo, não há nada de surpreendente, se eles conseguiram tornar bons apenas alguns homens, e talvez nenhum, pois recorreram a convicções falsas. A única sobre a qual eles se apoiaram é falsa: que é preciso procurar a virtude por ela mesma, o que refuta um argumento muito certo. Pois a virtude se transforma muito facilmente em pena. Mas ninguém suporta a pena senão por outra coisa; portanto, outros filósofos fingiram ter provado com certeza que há outra vida depois desta aqui, porque nesta o bem é geralmente um mal e um mal é geralmente um bem. "Eristeu reinará facilmente na doçura do lazer, enquanto o filho de Alcmene cansará, em todos os seus combates contra os monstros, os braços que sustentaram os céus." 24

Disso resulta também que se enganaram os que supuseram outra vida, mas que situaram a suprema felicidade na comida e na bebida, como os Judeus Talmudistas, ou nas coisas do amor como os Maometanos, enquanto que os cristãos afastam uns e outros da vida feliz, enquanto sinais

\footnotetext{
24 "Eurystheus regnera facilement dans la douceur du loisir / tandis que le fils d'Alcmène fatiguera dans tous ses combats / contre les monstres ces bras qui soutinrent le ciel." Cf. Sénèque, Hercule furieux, 526-8.

Hugo Grotius - Meletius ou carta sobre aquilo que é objeto de acordo entre os cristãos. Tradução por Weslin de Jesus Santos Castro. Revisão por Dominique Marie Phillipe Geneviève Boxus
} 


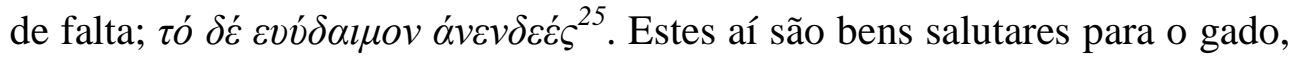
não para o homem. Porque neste, o espírito conduz em vantagem sobre o corpo; é preciso, para atingir a verdadeira felicidade, que o corpo seja assimilado pelo espírito, e não o espírito pelo corpo; e que ele se torne $\sigma \omega \mu \alpha$ $\pi v \varepsilon v \mu \alpha \tau \iota \kappa o ́ v^{26}$, um corpo espiritual, e não um $\pi v \varepsilon v \mu \alpha \sigma \omega \mu \alpha \tau \iota \kappa o ́ v$, um espírito corporal. Aristóteles o viu em parte; ele diz em Ética a Eudêmio:

\begin{abstract}
"A posse e a escolha do que é bom por natureza vêm da contemplação de Deus em detrimento do corpo, das riquezas, dos amigos ou de outros bens: é o melhor bem e a determinação mais bela. Aquilo que existe de tal modo que sua falta ou sua possessão excessiva impede de honrar e contemplar Deus é verdadeiramente um mal. É próprio da alma (e sua determinação mais excelente) estar consciente o menos possível da outra parte da alma desprovida de razão, enquanto tal., ${ }^{27}$
\end{abstract}

Eis então uma observação digna de interesse: tudo o que os outros quiseram colocar separadamente no Soberano Bem se encontra em totalidade no Soberano Bem dos cristãos. Pois, se procurares com o filósofo Jeronimo de $\operatorname{Rhodes}^{28}$ o prazer que se encontra na estabilidade e que chamamos de insensibilidade, ou com os Cirenaicos, aquilo que está no movimento, todos os dois estão presentes aqui: a ausência de toda a dor e o movimento mais doce, não aquele dos corpos (pois ele embaraça o espírito), mas aquele dos espíritos, isto é, o contentamento e a alegria. Mas, se com os estoicos, agrada-te a virtude, a verdadeira virtude está aqui também, no mais com esta prosperidade da vida cumprida que Aristóteles une a virtude.

Sobre a base desta natureza perfeita, que se relaciona com o homem e do Soberano Bem, que se relaciona com homem em totalidade, nós recusamos os epicureus e a seita judaica dos Saduceus. Pois a consequência daquilo que precede é que o corpo humano não perecerá jamais, ou que ele reviverá, e que o espírito também reviverá ou não perecerá jamais. Ora, a experiência mostra que os corpos perecem, eles reviverão então. Mas o espírito não perecerá jamais, é o que sustenta a religião cristã com a maior parte dos filósofos - pois os epicureus, segundo a palavra de um ancião, são chamados de filósofos apenas da mesma maneira que um homem

\footnotetext{
25 "Pois a verdadeira felicidade ignora a falta", Aristóteles EN, I, 5: 1097b5-11 \& X, 6: $1176 \mathrm{~b} 3$.

${ }^{26}$ Paul, I Cor. 15:44 "Semeamos um corpo psíquico, colhemos um corpo espiritual."

27 "La possession et le choix de ce qui est bon par nature viennent surtout de la contemplation de Dieu plutôt que du corps, des richesses, des amis, ou d'autres biens: c'est le bien le meilleur et la détermination la plus belle. Ce qui est tel que son manque ou sa possession excessive empêche d'honorer et de contempler Dieu est en verité un mal. C'est le propre de l'âme et sa détermination la plus excellente que d'être conscient le moins possible de l'autre partie de l'âme denuée de raison, en tant que telle." Ethique a Eudème, VIII, 1249 b 16-23. Grotius cita o texto grego.

${ }^{28}$ Cícero, De finibus II, § 8: "sumum bonum: nihil dolere."

Hugo Grotius - Meletius ou carta sobre aquilo que é objeto de acordo entre os cristãos. Tradução por Weslin de Jesus Santos Castro. Revisão por Dominique Marie Phillipe Geneviève Boxus
} 
pintado é chamado de homem, a religião cristã, digo eu, solidária não apenas com a crença mais antiga de quase todos os povos, mas também com a razão por si mesma que nos ensina que o pensamento e, no espírito, a imagem de Deus desprovida de sofrimento. Tendo descoberto o fim da religião, vejamos agora em que ela consiste.

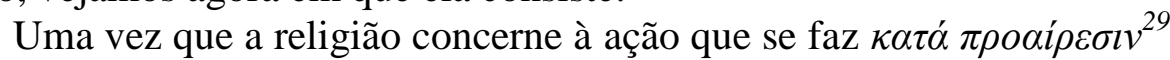
e que o entendimento precede todas as ações da vontade, a religião tem necessariamente duas partes: uma $\theta \varepsilon \omega \rho \eta \tau \iota \kappa \eta v^{30}$, a outra, $\pi \rho \alpha \kappa \tau \iota \kappa \eta^{\prime 3} v^{31}$; os $\delta o ́ \gamma \mu \alpha \tau \alpha^{32}$ constituem a primeira, os $\pi \alpha \rho \alpha \nu v \varepsilon ́ \sigma \varepsilon l \varsigma^{33}$ a segunda. Sêneca depois de Cícero ${ }^{34}$ traduziu estes termos em latim por decreta e praecepta; todo o ensino sobre os deveres e sobre os costumes reside conforme sua demonstração nestas duas categorias. Os princípios são ainda chamados de opiniões $^{35}$, dogmas fundadores ${ }^{36}$ ou teses ${ }^{37}$. Em toda ciência prática os princípios não devem ser exteriores ao sujeito, nem redundantes, mas devem indicar o que põe a ação em desenvolvimento ${ }^{38}$, ou o conteúdo e as modalidades daquilo que é preciso fazer. Por isso, uma vez que a religião se situa entre o homem e Deus, os princípios da religião concernem a Deus e às coisas divinas, ao homem e às coisas humanas, não em si mesmas, mas numa relação mútua.

Dentre esses princípios, o primeiro lugar cabe a justo título à afirmação de que Deus é um, o que prova pelos mesmos argumentos a crença de que Deus é. Com efeito, tudo provém de um único ser e existe em vista de um único; a natureza muita perfeita de Deus, sua beatitude e o governo de todas as coisas o exigem. E, no entanto, quão grande parte do gênero humano foi cativa outrora deste erro inescusável do $\pi 0 \lambda v \theta \varepsilon o ́ \tau \eta \tau o \varsigma^{39}$, e o é ainda agora.

A religião cristã atribui ainda a Deus aquilo que pode ser dito ou pensado de mais eminente e rejeita todo o resto. Ela afirma, com efeito, que

\footnotetext{
${ }^{29}$ Segundo uma escolha refletida ou responsável. A expressão é deixada em grego e não é traduzida por Grotius em toda a sequência do texto.

${ }^{30}$ Teorético ou especulativo.

${ }^{31}$ Prática.

${ }^{32}$ Os princípios.

${ }^{33}$ Os preceitos ou ainda as exortações de onde vem o nome de parenético dado à parte da filosofia que oferece conselhos para a vida moral. Cf. Cícero, Off. I, 1; II, 32; Sêneca, Ep. 94:31.

${ }^{34}$ Cf. Cícero, Ac. 1, 27 \& 29; Sêneca, Ep. 95:10; 95:60.

${ }^{35}$ Placita $=\alpha \rho \varepsilon \sigma \kappa o ́ v \tau \alpha$.

${ }^{36}$ Scita $=\delta o ́ \gamma \mu \alpha \tau \alpha$; os termos placita e scita designam os dogmas fundamentais das escolas, cf. Aetius, Stromates do pseudo Plutarco (Diels, Doxogr. Graeci, Berlim, 1878).

${ }^{37}$ Sententiae. Cf. Seneca Ep. 95:10 "Nulla ars contemplativa sine decretis suis est, quae graeci vocant $\delta o ́ \gamma \mu \alpha \tau \alpha$, dogmata, nobis vel decreta licet apellare vel scita vel placita. Não existe ciência especulativa que não tenha seus princípios, para os quais os gregos tem um termo $\delta o ́ \gamma \mu \alpha \tau \alpha$, traduzido em latim por diversos equivalentes decreta, scita, placita."

${ }^{38}$ No estoicismo clássico, isso designa a ação do hegemônico.

${ }^{39}$ Politeísmo.

Hugo Grotius - Meletius ou carta sobre aquilo que é objeto de acordo entre os cristãos. Tradução por Weslin de Jesus Santos Castro. Revisão por Dominique Marie Phillipe Geneviève Boxus
} 
Deus é absolutamente simples, infinito, excelente; reciprocamente ela nega de forma categórica que ele seja corporal, composto, mutável, limitado no espaço ou no tempo. Plutarco diz que os Judeus creem em um $\theta \varepsilon o ́ v$

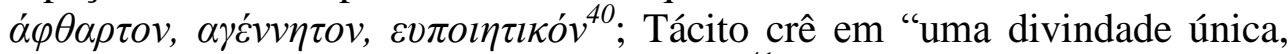
suprema, eterna que não muda nem perece." ${ }^{, 41}$

Nessa natureza una e simples, entende-se primeiro o que é ser, em seguida o que é a razão divina, por fim a virtude; parece que Aristóteles tenha observado as duas últimas em Deus, chamando-as de Novv kai $\varepsilon v \varepsilon ́ \rho \gamma \varepsilon \iota \alpha v^{42}$. Pois se ele não as tivesse, ele seria menos perfeito que as coisas que ele fez. A razão é ainda chamada de $\lambda o ́ \gamma o \varsigma$ e $\sigma o \varphi i ́ \alpha$ pelos Platônicos, mas os Cristãos explicam mais claramente a coisa em si e seus nomes. A virtude própria de Deus é chamada ${ }^{43}$ novamente assim entre os cristãos, e também Espírito, termo que não designa apenas $\tau o \alpha \sigma \omega ́ \mu \alpha \tau o v^{44}$, mas ainda

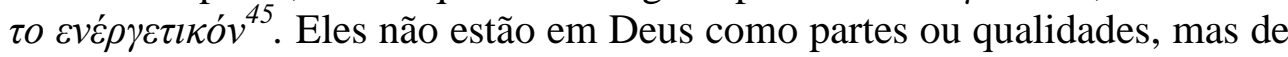
outra maneira inefável, distintas entre si, de tal maneira que $\tau \rho \varepsilon \iota \varsigma$

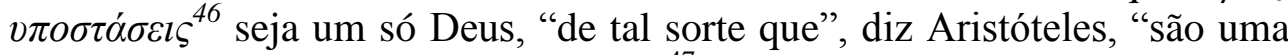
mesma coisa o intelecto e o inteligido."47

Embora a razão humana não possa encontrá-lo por ela mesma, ela admite isso facilmente quando se lhe diz que acontece assim com Deus. Porque ela vê que tudo isso é coerente com a majestade divina e ela não deve temer admiti-lo, uma vez que o fato de não compreender como eles são três e um se produz também para nossa alma, que é tão inferior: nós admitimos a natureza própria da alma, o entendimento e a vontade, e, no entanto reconhecemos que o espírito é um e indivisível. Mesma coisa para o sol: nós sabemos... ${ }^{48}$

Visto que a perfeição do entendimento consiste em saber o mais possível, e a excelência da vontade consiste em querer e agir, segue-se que Deus é onisciente quanto à sabedoria, excelente quanto à virtude, e, logo, ele conhece bem o que é mal, mas Ele não o quer no sentido próprio, nem o provoca; o que é o principal fundamento da piedade. Calai-vos então, poetas, outrora únicos mestres de teologia, criticados a justo titulo por

\footnotetext{
40 "Deus incorruptível, não gerado e providencial." (criador das coisas belas); G.P. Meyjes da como referência provável: Mor. 1051F.

${ }^{41}$ Tácito Hist. V 5: "Judaei mente sola unumque numen intelligunt (...) summum illud et aeternum neque imitabile neque interiturum."

${ }^{42}$ Pensamento e ato, Aristóteles, Metafisica lambda 7, 1072b21-23.

${ }^{43}$ Logos.

${ }^{44}$ Incorpóreo.

45 Aquilo que é ativo.

46 Três hipóstases. Cf. Stobee Dicta, prologo "De hypostasium quoque distinctione quanquam eo per se pertingere non potest humana ratio aliquid ex traditione veteri haussisse putator Plato et ut quidam existimant etiam Aristoteles." Citado por Meyjes, Op. cit., p. 144.

${ }^{47}$ Novv kaı voptóv. Aristóteles. Metafisica, $1072 \mathrm{~b} 21$.

${ }^{48}$ A continuação deste trecho não consta no texto original. (N.T.)

Hugo Grotius - Meletius ou carta sobre aquilo que é objeto de acordo entre os cristãos. Tradução por Weslin de Jesus Santos Castro. Revisão por Dominique Marie Phillipe Geneviève Boxus
} 
Platão e Varrão, por terem contado ações criminosas de vossos deuses para os próprios homens: combates, adultérios e outros crimes. Calai-vos então, vozes ímpias: "Ah! Ah! É um mal vindo dos deuses para os homens / Ver o bem e não segui-los." 49 Ou ainda: "Deus implanta o crime entre os mortais, quando ele quer arruinar completamente a casa destes." ${ }^{, 50}$ Ou ainda: "Terem me tornado pecador será também um crime dos deuses." ${ }^{51} \mathrm{Ou}$ ainda: "Isso vos agrada, o deuses, depois de terem desordenado tudo, considerar como crime nossos erros." ${ }^{, 52}$ Essa opinião apaga a religião. Como se poderia amar a Deus e odiar o mal, se se acreditar que ele é o autor do mal? Este discurso é mais verídico. "Se os deuses fazem alguma coisa má não são deuses." ${ }^{53} \mathrm{E}$ Cleante:

"Sem ti, ó Deus benfazejo, não se produz nada sobre o solo da terra, nem sobre as águas do mar, nem no reino dos raios que trovejam nas alturas, exceto os estragos que os malvados fazem em sua demência." 54

A reta razão e a religião crista ensinam, entretanto, que Deus se preocupa destes próprios males que provêm dele, e que ele faz o papel regulador. São duas crenças de maior utilidade da religião: a onisciência e a perfeitíssima bondade de Deus. A onisciência faz com que em tudo o que é mais secreto, não apenas os fatos, mas também os pensamentos, nós temamos a presença de Deus; a bondade faz com que nos esforcemos para alcançá-lo segundo essa palavra de Pitágoras: ć́ $00 v \theta \varepsilon \omega^{55} \mathrm{e}$ esta de Cristo: "seja perfeito como vosso Pai e perfeito". Para resumir tudo o que dissemos sobre Deus: nós devemos amá-lo pela sua natureza perfeitíssima, honrá-lo pela sua muito grande sabedoria, e amá-lo mais do que tudo pela sua extraordinária bondade.

\footnotetext{
49 "Hélas! Hélas! c'est un mal venu aux hommes des dieux / De voir le bien et ne pas le suivre." Eurípedes, fragmento 841. Citado por Plutarco Mor 33E \& 446A (Sobre a virtude moral).

50 "Dieu implante le crime chez les mortels / Qaund il veut ruiner completement leur maison." (Ésquilo, fragm. 292. citado por Platão Rep. 380a; Grotius traduz: Deus provoca a culpa quando ele ataca casas sadias.

51 "M'avoir rendu pecheur sera un crime aussi pour les dieux." Lucain Farsale, II, 288.

52 "Cela vous plaît-il, o dieux, après avoir tout mis sens dessus dessous, de nous tenir à crime nos erreurs?" Lucain Farsale, VII, 58-9.

53 "Si les dieux font quelque chose de mal, ce ne sont pas des dieux." Eurípedes, fragmento 292. citado por Plutarco Mor. 21A et 1049E.

54 "Sans toi, Dieu bienfaisant, rien ne se produit sur le sol de la terre / Sur les flots de la mer, au royaume de la foudre qui tonne dans les hauteurs / sauf les ravages que les mechants font eux-memes dans leur démence." Cleante Hino a Zeus, 15-17. "Nenhuma obra se realiza sem ti, ó Divindade, nem sobre a terra, / Nem na região etérea da abóbada divina, nem sobre o mar / Exceto aquilo que os malvados conseguem em sua loucura.." (traducao Brehier, in Les Stoiciens, Pleiade, p. 7)

55 “Suis Dieu!" Escola pitagórica, C VI, Présocratiques, Edição Pléiade, tradução Dumont, p. 591.

Hugo Grotius - Meletius ou carta sobre aquilo que é objeto de acordo entre os cristãos. Tradução por Weslin de Jesus Santos Castro. Revisão por Dominique Marie Phillipe Geneviève Boxus
} 
Agora, se se considerar Deus não apenas em si mesmo, mas $\varepsilon v$ $\sigma \chi \varepsilon ́ \sigma \varepsilon l^{56}$ em outras coisas, esta mesma religião mostra dois aspectos de Deus: ele é criador e regente de todas as coisas. Que ele seja criador provase evidentemente com os mesmos argumentos pelos quais se demonstra que ele existe, a saber, pela série de causas que não pode existir sem se apoiar sobre uma causa primeira; esse ponto, aliás, aumenta a honra de Deus e facilita o caminho da piedade. Platão, que quer que o mundo seja engendrado, e Aristóteles, que quer que este seja eterno, enganam-se seguramente, mas suas demonstrações provam isso em que nós cristãos acreditamos. Pois Platão deduziu corretamente que o mundo começou um dia e Aristóteles, não menos corretamente, que ele não é gerado; segue-se então que ele foi feito.

Quando falamos do mundo, não entendemos apenas o visível, aí compreendido o homem, mas também os $\alpha o ́ \rho \alpha \tau \alpha^{57}$, a saber, os espíritos ou as naturezas inferiores a Deus, mas superiores ao homem, naturezas inteligentes e ativas, que muitos chamaram deuses ou daímovas ${ }^{58}$.

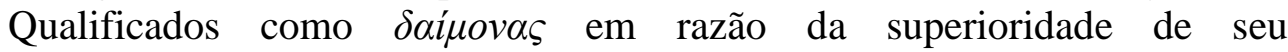
entendimento, mas impropriamente chamados de deuses. Pois se o $\pi \sigma \lambda v \theta \varepsilon o ́ \tau \varepsilon \varsigma^{59}$ foi condenado por razões certas, segue-se que é impróprio que eles sejam chamados de deuses em razão de certa participação na majestade divina. Neste ponto os doutores dos cristãos suprimiram radicalmente o erro daqueles que, dando-lhe as mesmas honras e o mesmo nome, igualavam a obra ao obreiro; eles recusaram este termo e preferiram chamá-los de anjos, a fim de que se os compreenda como ministros de Deus, não como seus associados.

Afirmando que Deus é regente, não recusamos apenas os encontros fortuitos de átomos dos Epicureus, mas também a força fatal dos Estoicos, enquanto princípios igualmente nocivos à piedade. Por essa operação de direção, Deus conserva e não destrói a natureza das coisas que ele instituiu, e particularmente a $\pi \rho o \alpha i \rho \varepsilon \sigma l \varsigma$ atribuída aos espíritos. O que resolve esta questão que por muito tempo atormentou os filósofos: $\tau o v \theta \varepsilon \sigma v \quad \tau \alpha \alpha \gamma \alpha \theta \alpha$ $\delta \iota \delta o ́ v \tau o \varsigma, \pi o ́ \theta \varepsilon v \tau \alpha \kappa \alpha \kappa \alpha{ }^{60}{ }^{60}$. Resposta: da $\pi \rho o \alpha i \rho \varepsilon \sigma \iota \varsigma$, faculdade certamente boa quando Deus a concede, mas que pode por si mesma transformar-se num mal, ainda que Deus nos proíba e nos dissuada disso, sem, todavia impedi-la usando de força, para não suprimir a liberdade justamente dada uma vez por todas, e sem a qual não pode haver recompensa. $\mathrm{O}$ mal ou o pecado procede da vontade muito livre do homem e desses espíritos inferiores que se afastam voluntariamente da lei pelas suas obras. Sobre este

\footnotetext{
${ }^{56} \mathrm{Na}$ sua relação.

${ }^{57}$ As realidades invisíveis.

${ }^{58}$ Demônios.

${ }^{59}$ Politeísmo.

${ }^{60}$ Se os bens vêm de Deus, de onde vêm os males? "Si les biens viennent de Dieu, d'ou viennent les maux?” Titulo da dissertação 41 de Máximo de Tyr. Cf. Plotino, I, 9.

Hugo Grotius - Meletius ou carta sobre aquilo que é objeto de acordo entre os cristãos. Tradução por Weslin de Jesus Santos Castro. Revisão por Dominique Marie Phillipe Geneviève Boxus
} 
tema nós encontramos a tese dos Maniqueístas e de seus pares, que puseram a matéria (ou algum outro princípio necessário) como princípio do mal e sustentaram que alguns eram provocados pela natureza e não podiam de modo algum ser nem tornar-se bons. Mas estas crenças são injuriosas para com Deus e tiram do homem uma verdadeira dor de seus pecados e o ardor do arrependimento.

Passemos agora aos princípios que concernem ao homem. Alguns já foram evocados: o homem é composto de um corpo e de um espírito. Ele tem a potência da $\pi \rho o \alpha i ́ \rho \varepsilon \sigma \iota s$. Ele é o ser mais nobre e mais digno de todas as realidades visíveis, e mais, o mestre das outras. Acrescentemos que Deus o criou bom certamente, pois aquele que é o melhor não pode fazer algo ruim, ainda mais, como disseram alguns filósofos de acordo com a filosofia cristã, o homem é uma imagem de Deus, criado sobre o próprio modelo de Deus, e dotado da faculdade de poder se aproximar mais e mais deste modelo por meio de seus esforços. No início, o homem não foi criado múltiplo, mas um só, do qual provieram os outros; crença tão verdadeira que é a melhor e a mais eficaz para uma caridade e uma amizade mútuas, visto que os jurisconsultos também provam muito validamente que "é criminoso para um homem querer mal a outro", já que, "a natureza constitui entre nós uma espécie de parentesco".

Contra os Estoicos, e de acordo com outros filósofos, os cristãos sustentam muito justamente que Deus também dotou o homem de $\pi \alpha ́ \theta \eta^{61}$, o que demonstra bem a natureza própria do homem na qual até mesmo alguns médicos contam alguns membros - que são fonte e sede das paixões. Esta tese é também de grande importância para a piedade, pois a doutrina contrária - a menos que se sirva obstinadamente de um vocabulário oposto ao uso - torna as pessoas cruéis e impiedosas.

A $\sigma \chi \varepsilon \dot{\varepsilon} \sigma \iota \varsigma^{62}$ do homem para com Deus é aquilo que dissemos mais acima: ele foi criado para prestar um culto a Deus. Todos os filósofos, nós o dissemos, admitiram e alguns o concluem justamente sobre a constituição do corpo humano que é reta e olha para o céu. Daí vem a denominação que

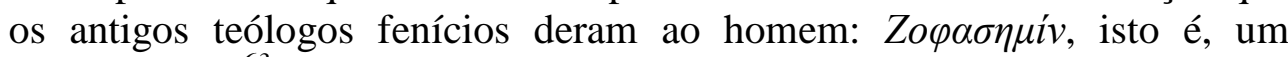
vраvóбколоv. ${ }^{63}$

Como poderia ser que o homem não tenha sido criado principalmente para fazer o que ele podia e, sobretudo o que devia fazer? Com efeito, ele podia prestar culto a Deus, pois ele dispunha para isso do espirito, e ele o devia, não somente em razão da eminência absoluta da natureza divina, mas, sobretudo, em razão das suas benfeitorias, inclusive isso: por ele que ele se tornara homem, que ele era mais nobre do que os outros seres, que tantas coisas enfim haviam sido destinadas para servir ao

${ }^{61}$ Paixões. O termo insiste sobre o aspecto passivo da afetividade. Cf. Lactance, Inst. VI, 15-17.

${ }^{62}$ A relação.

${ }^{63}$ Aquele que olha o céu. Eusébio: Prep. evang. , I, 10, 2.

Hugo Grotius - Meletius ou carta sobre aquilo que é objeto de acordo entre os cristãos. Tradução por Weslin de Jesus Santos Castro. Revisão por Dominique Marie Phillipe Geneviève Boxus

Griot - Revista de Filosofia, Amargosa, Bahia - Brasil, v.10, n.2, dezembro/2014/www.ufrb.edu.br/griot 
seu uso. Prestar um culto a Deus abarca tudo isso: amá-lo, admirá-lo, reverenciá-lo, desejar agradar-lhe, temer desagradar-lhe, detestar o que é contràrio à sua lei. Como tudo isso carrega o nome de $\pi \alpha \theta \omega v$, isso prova o que se disse anteriormente, que não é preciso extirpar essas paixões do homem. Pois, não basta cumprir a tarefa prescrita, é preciso fazê-la empregando nisso toda sua alma e todas as suas faculdades. Eis em resumo o que homem deveria ser.

Passemos agora aos princípios que, com a ajuda da experiência, definem o que existe. Admite-se que o homem se comporta muito diferentemente do que ele deveria: com efeito, ele é ingrato para com Deus e realmente mau. Ao passo que ele deveria amar a Deus com toda sua alma, render-lhe culto, preferi-lo a todo o resto, apreciar como uma graça suas imensas benfeitorias, a consciência de cada um comprova que tudo ocorre de outra forma.

Deus, fazendo jus a sua natureza, quis que nenhuma coisa fosse recomendável ao homem senão outro homem enquanto imagem de Deus e parente do homem. A razão nos ensina uma e outra: a união e o parentesco mais estreitos são aqueles que vêm de uma origem comum e do sangue, e, se quisermos ser reconhecidos, devemos amar não apenas aquele que nos cumulou de benfeitorias, mas também aqueles que o tocam mais de perto. Pelo contrário, nós vemos a confusão causada em toda a parte pelo ódio e pelas dissensões. Pior, varias ações que nos parecem boas são más, pois é mal aquilo que é privado de uma parte de sua retidão, uma vez que o bem não é nenhum outro senão aquilo que é totalmente bom: "o bem é simples, o mal é múltiplo." ${ }^{64}$ Daí vem que não há alma pura e íntegra e não há intenção realmente firme para servir a Deus, lá onde não pode haver conveniência perfeita $^{65}$ ou ação reta.

Mas o homem não deve surpreender-se em cair no pior, já que inúmeros delitos excedentes da forca de sua natureza inferior - o que atesta a historia de todos os povos - provam claramente que alguns espíritos superiores se viraram para o mal, pois se esforçaram com todos os meios para dividir com o homem sua maldade. Eles conseguiram isso de tal forma que os sentidos do homem lhe oferecem mais tentações de pecar que ocasiões de virtudes. Que esta depravação se difunda sobre todo gênero humano, se sua consciência não o repetisse a cada um, ao menos esta miséria comum aos homens e a natureza (transformada em madrasta em vez

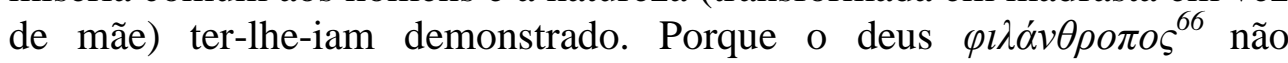

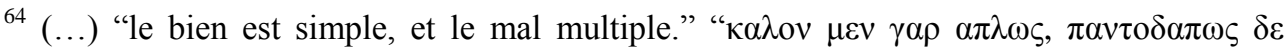

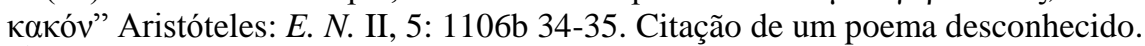

${ }^{65} \mathrm{~K} \alpha \tau$ ó $\rho \theta \omega \mu \alpha=$ officium perfectum pertence ao vocabulário estoico. Cf. Cícero De Off. I 8

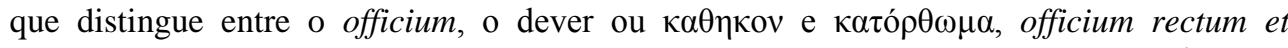
perfectum, ação reta e conveniência perfeita. Cf. também Sêneca Ep. 95:57 "Actio recta non erit nisi recta fuerit voluntas."

${ }^{66}$ Amigo dos homens.

Hugo Grotius - Meletius ou carta sobre aquilo que é objeto de acordo entre os cristãos. Tradução por Weslin de Jesus Santos Castro. Revisão por Dominique Marie Phillipe Geneviève Boxus
} 
suportaria que a vida dos homens fosse, nesse sentido, sujeita a tribulações, se não os encontrasse todos sujeitados ao erro.

Os cristãos rejeitaram também a justo título outro erro dos Estoicos: a tese da igualdade dos pecados. A própria consciência afirma que é falso, ela que nos acusa mais ou menos gravemente segundo a amplitude de nossos erros. No mais, as próprias leis são desiguais em função da diversidade de seu objeto, uma mais importante, outra menos. Há fatos mais distantes de uma lei do que outros; isso se dá como linhas oblíquas: não é porque todas elas se afastam da linha reta que sua inclinação é igual. Não é preciso, entretanto, julgar um erro sem importância, mesmo se ele for muito leve comparado a outros.

Todos os pecados têm em comum ofender o Rei supremo, o Pai melhor, o benévolo mais generoso, sobretudo aqueles do homem que Deus cumulou de todas as coisas e gratificou com tantos dons admiráveis. Mas, uma vez que todos os homens se afastam da lei de Deus, segue-se logo que todos são escravos dos vícios, consequentemente sujeitos ao castigo e que

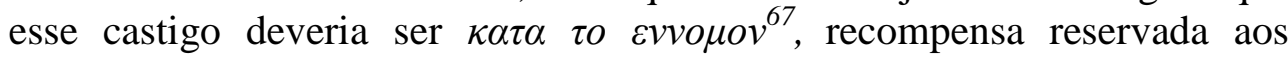
observadores da lei.

Desse princípio decorre que todos os vícios conduzem ao precipício. "É realmente faltar com o bom senso", diz Aristóteles ${ }^{68}$, "ignorar que o hábito provém das ações, no que se refere às coisas singulares". O que ele explica em dois exemplos: o exemplo da pedra lançada; aquele que a lançou a tinha em sua mão antes de lançá-la e podia não lançá-la, uma vez que ela foi lançada, ele não podia mais fazê-la voltar; e o exemplo de um homem doente por intemperança e negligência da medicina: ele teve o poder de não ficar doente, mas agora isso não existe. Depois ele acrescenta com fineza: "assim faz parte do homem injusto ou intemperante: no início, era possível não se tornar tal coisa, isso explica que eles o são voluntariamente, e agora que eles se tornaram assim, não podendo mais não sê-lo." ${ }^{69}$ Sêneca diz isso também, não sem elegância: "dentre outros inconvenientes da condição mortal, é preciso contar a cegueira do espírito que estimula menos errar do que amar o erro." 70

Deus retira a justo titulo seu socorro, o qual é certamente necessário para o homem viver retamente segundo a lei de Deus, daqueles que deslealmente se afastaram dele. Além disso, aconteceu que no começo do

\footnotetext{
${ }^{67}$ Literalmente: na medida da lei ou em proporção.

${ }^{68}$ Aristóteles E. N. III, 7, 1114a12-22. Grotius cita o texto grego.

69 “ainsi en est-il de l'homme injuste ou intempérant : au début il leur était possible de ne pas devenir tels, et c'est ce qui fait qu'ils le sont volontairement, et maintenant qu'ils le sont devenus, il ne leur est possible de ne pas l'être. Aristóteles E. N. III, 7, 1114a19-22. Tradução Tricot.

70 "entre autres inconvénients de la condition mortelle, il faut compter l'aveuglement de l'esprit qui pousse moins à errer qu'à aimer l'erreur." Seneca De ira II, 10, 1 .

Hugo Grotius - Meletius ou carta sobre aquilo que é objeto de acordo entre os cristãos. Tradução por Weslin de Jesus Santos Castro. Revisão por Dominique Marie Phillipe Geneviève Boxus
} 
gênero humano, houve nas gerações seguintes maus engendramentos, má educação, e por toda parte, maus exemplos.

Esta doutrina é de longe a mais salutar, pois ela ilustra a bondade de Deus no que ele continuou a amar os homens, mesmo aqueles que mereciam menos, e ela causa também no homem aquilo que é a melhor salvaguarda: que ele se porte de maneira modesta, o que falta em quase todos os filósofos. Porque nenhum deles considera o homem como responsável, e nenhum conduz a $\tau \alpha \pi \varepsilon \imath v o \varphi \rho o \sigma v ́ v \eta v^{71}$, como o faz a religião cristã. É ainda uma vantagem perdoar mais facilmente os outros, quando se se lembra que não se é inocente. Sêneca: "se quisermos ser juízes imparciais, devemos nos convencer logo que nenhum dentre nós está isento de culpa." 72

Nós condenamos então a $\theta \varepsilon o \mu \alpha \chi i \alpha v^{73}$ dos Estoicos; entre eles, Sexto negava que "Júpiter fosse mais poderoso que um homem bom" e dizia que "Deus não supera o sábio em felicidade, mesmo que Ele o faça em duração." Até aonde não conduziu sua loucura para dizer que Deus estava superado pelo homem sábio visto que o sofrimento do mal e o sábio estão acima disso. Do mesmo modo são condenados também os $\kappa \alpha v \chi \eta ́$ $\mu \alpha \tau \alpha^{74}$ dos Fariseus, e todos aqueles que creem poder por suas próprias forcas evitar a punição ou merecer a recompensa.

Uma vez então que o homem, em razão de seus vícios, permanece sujeito a uma disposição viciosa e ao castigo, segue-se que toda religião pereceria se ela não encontrasse o caminho da remissão e da reparação dos erros. Com efeito, aquele que merece uma punição não pode esperar recompensa e aquele que está imerso nos vícios não pode esperar sair destes por si mesmo. Mas o fato de que a religião não seja destruída pode se deduzir disso: Deus estende o gênero humano e prorroga o usufruto deste mundo para ele. Pois senão, para que o homem lhe presta culto? Há realmente uma remissão dos pecados e reparação do homem decaído; não basta apenas que haja uma remissão dos pecados, mas também, que a confiança dos homens nesta seja de tal modo que aquele que está certo do perdão se aplique a agradar a Deus. Esta segurança é um dom próprio da religião cristã. Zózimo, autor não cristão, dizia que ela era "a promessa de estar libertado de todo o pecado e o livramento de toda impiedade." E, em outro momento, ele a chamava de "a convicção ${ }^{75}$ que retira todo o pecado e que promete aos ímpios que se aproximam dela libertá-los imediatamente do pecado." 76

\footnotetext{
${ }^{71}$ A humildade.

72 "Si nous voulons toujours être des juges équitables, persuadons-nous d'abord qu'aucun d'entre nous n'est exempt de faute." Sêneca De ira, II, $28,1$.

${ }^{73} \mathrm{O}$ combate dos deuses. Cf. Cícero DND e Filódemo, De pietate.

${ }^{74}$ As vanglórias.

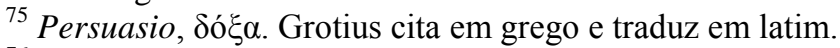

76 "la conviction qui enlève tout péché et qui promet aux impies qui la rejoignent de les libérer immédiatement du péché."

Hugo Grotius - Meletius ou carta sobre aquilo que é objeto de acordo entre os cristãos. Tradução por Weslin de Jesus Santos Castro. Revisão por Dominique Marie Phillipe Geneviève Boxus
} 
Mas aquilo que alimenta esta certeza importa muito. $\mathrm{O}$ quanto se pode perigosamente errar sobre este ponto é e o que mostra Platão quando ele critica muito severamente como corruptoras da moral estas religiões que por meio de ritos de iniciação prometiam um perdão fácil e barato. Vendo este perigo, os sucessores de Platão - e entre eles Porfírio - negaram que se pudesse encontrar um método certo e universal de purgação das almas, assim eles chamam de $\theta \varepsilon o v \rho \gamma i ́ \alpha v$. No entanto, sem essa descoberta, não há religião. É preciso então reconhecer que sem uma revelação divina os homens não poderiam ter consolo. Entretanto, vale a pena verificar como dentre pessoas que se agitam nas trevas, umas se aproximaram mais dela do que outras.

Em primeiro lugar, todos os povos ficaram de acordo sobre este

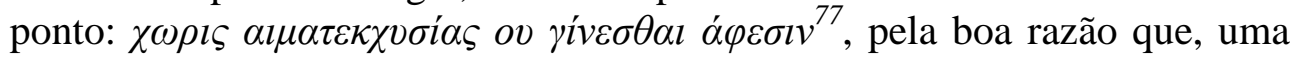
falta cometida em relação a Deus não pode ser expiada por um suplício menor que a morte. Eles tiveram que saber também que o valor dos animais é demasiadamente fraco para servir de vitima de substituição no lugar do homem. Por isso, certos povos imolaram homens, em que primeiramente eles foram homicidas, pois ninguém tinha autoridade para prescrever tal ato, eles cometeram aí uma segunda falta: a de acreditar que um homem - que devia ele mesmo a pena por sua própria conta — poderia se tornar vitima expiatória para outros homens; ora, tivessem achado um homem inocente e este não existe - nenhum sequer teria a força suficiente para redimir um povo ou o gênero humano.

Os povos e a maioria dos filósofos estão de acordo ainda sobre isso: acreditou-se que era preciso procurar para o homem, de certo modo reconhecido como estranho a Deus pela sua falta, um mediador que quis realmente se intrometer entre o homem e Deus. Daí vem que eles se prestaram ao culto dos demônios, pois estimara sua natureza intermediária entre a dos homens e a de Deus. Mas, como observa Porfírio, o vício da ignorância ${ }^{78}$ não pode ser apagado por outro meio senão pela inteligência paterna $^{79}$. Mas a depravação dos homens se conjuga com a maior ignorância e cegueira.

A verdade cristã une tudo isso em uma coisa só, uma vez que ela ensina que foi dado ao homem um $\mu \varepsilon \sigma i \tau \eta v^{80}$, não alguém que não foi nem homem nem Deus, mas um e outro ao mesmo tempo, ele mesmo que é $\lambda o ́ \gamma o v \pi \alpha \tau \imath \iota \delta^{8} v^{81}$, que por virtude divina foi feito verdadeiro homem para poder expiar ${ }^{82}$ pela efusão de sangue. Pois, para que ele pudesse morrer, era preciso que ele fosse homem, e não podia devolver a vida ao outros se ele

\footnotetext{
77 “sem efusão de sangue, não há remissão da culpa” Epístola aos Hebreus, 9:22.

${ }^{78} \tau \eta \varsigma$ arvoías.

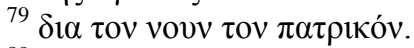

${ }^{80}$ Um mediador Paulo, Tim. 2:6.

${ }^{81} \mathrm{O}$ verbo paterno ou do pai.

${ }^{82} \delta \mathrm{l}^{\prime} \alpha \mu \alpha \tau \varepsilon \kappa \chi v \sigma i ́ \alpha \varsigma$.

Hugo Grotius - Meletius ou carta sobre aquilo que é objeto de acordo entre os cristãos. Tradução por Weslin de Jesus Santos Castro. Revisão por Dominique Marie Phillipe Geneviève Boxus
} 
mesmo não fosse Deus. O fruto de sua morte é superior a todos os outros. Pois, ele impede primeiro que os homens não superestimem seus pecados, como o fazem aqueles que pensam poder ser livres por alguma vítima de pouco preço ou por uma oferenda menor. Não pode ser gravíssima a culpa cuja $\kappa \alpha ́ \theta \alpha \rho \mu \alpha^{83}$ foi o verdadeiro filho do próprio Deus. Em seguida, sob outro ponto de vista, isso compensa a desesperança dos homens, cuja consciência não pode satisfazer-se por outras expiações. Ela o pode apenas naquilo em que ela vê um preço correspondente a suas culpas. Enfim, não poderíamos atestar mais eficazmente o amor de Deus em relação aos homens, e, logo, nos incitarmos a amar de volta um pai tão generoso.

A historia de Zaleucos é bem conhecida: ele editara uma lei segundo a qual se poderia arrancar os olhos dos adúlteros; tendo seu filho cometido este crime, ele o livrou da cegueira arrancando um olho seu e o outro de seu filho. "Assim", diz Valério Máximo, "ele pagou o suplício devido ao preceito legal, e compartilhou por uma admirável equidade no pai misericordioso e no legislador justo. ${ }^{, 84} \mathrm{O}$ Cristo fez mais que isso, pois para nos livrar inteiramente do castigo, tomou para si o nosso lugar. Como já havíamos dito em uma ocasião semelhante, isso não é menos crível, porque não compreendemos como Deus pode se identificar com o homem. Pois, não compreendemos que tipo de aliança e laço há entre nossa alma e nosso corpo, e não duvidamos, entretanto, que o conjunto não seja um só homem.

A maioria dos filósofos pensa que Deus mora nos espíritos dos homens; é neste sentido que o platônico Amélio citava bem essa passagem

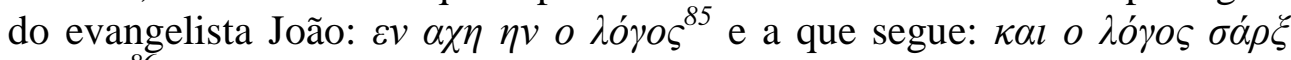
$\varepsilon \gamma \varepsilon ́ v \varepsilon \tau o^{86}$; mas ele interpretava estes termos obliquamente o modo como Deus habita em todos os homens santos; isso difere enormemente desta forma superior e inefável que se chama $\kappa \alpha \theta \varepsilon v \omega \sigma l v v \pi o \sigma \tau \alpha \tau \iota \kappa \eta v^{87}$, ainda que baste ser um caminho que conduz a crença. Mas as obras admiráveis do Cristo arrancam o consentimento — apesar da lentidão humana — mais eficazmente que toda outra arma, porque elas superam toda a força do homem e dos espíritos criados de tal maneira que, tendo sido tudo pesado, seja muito mais difícil não acreditar que foi Deus que fez isso do que acreditar. Sobretudo porque estas mesmas obras, o tempo do nascimento de Cristo, seus ancestrais e sua pátria, toda sua vida e sua morte, foram preditas por uma única voz alguns séculos antes pelos profetas.

É preciso ver agora a quem é acessível o perdão de que falamos. A religião cristã ensina que é acessível a todo o gênero humano, e os Judeus,

\footnotetext{
${ }^{83}$ Vitima expiatória.

84 “Ainsi, il paya le supplice dû selon la loi, et se partagea par une admirable équité en père miséricordieux et en

législateur juste."

${ }^{85}$ No princípio era o Verbo.

${ }^{86} \mathrm{E}$ o verbo se fez carne.

${ }^{87}$ Segundo a união hipostática.

Hugo Grotius - Meletius ou carta sobre aquilo que é objeto de acordo entre os cristãos. Tradução por Weslin de Jesus Santos Castro. Revisão por Dominique Marie Phillipe Geneviève Boxus
} 
pelo contrário, querem ciosamente que todos os povos (exceto eles) sejam privados desta esperança. Mas todos não a alcançam efetivamente, pois este perdão é oferecido sob a condição de penitência e de fé, sendo a primeira requerida para todo perdão. Nenhum sábio concede perdão a alguém de um crime se ele souber que este alguém não se arrepende do crime, não fosse assim, as maldades dos pecadores provocariam a impunidade. "Suportando uma antiga injustiça, tu suscitarias uma nova." 88

A segunda condição, a veracidade de Deus a exige, pois é um ultraje abominável não confiar nas promessas, e é igualmente necessário, pois não há outro meio de receber individualmente o que é oferecido universalmente, senão pela fé. Como já disséramos, ninguém pode se erguer para amar a Deus e prestar-lhe um culto, exceto aquele que concebeu anteriormente a segurança firme no perdão de suas culpas passadas. Isso está totalmente de acordo com a sã razão. "O arrependimento", como foi dito, "é algo divino, que salva aqueles que pecaram. A razão apaga as outras dores, apenas o arrependimento é produzido pela razão, ferida pela vergonha e punida por ela mesma" ${ }^{, 89}$. E assim como este arrependimento é muito útil para corrigir o homem, assim também a confiança em Deus importa muito à glória de Deus mesmo. Daí vem que este perdão é tão verdade que o querem os filósofos, "uma graça que não está de acordo com a lei, nem contra a lei, mas acima da lei e para a lei.", 90

Para compreender isso mais claramente, passemos à regeneração do homem que segue na ordem a remissão. Alguns remédios são necessários para isso: o primeiro é expurgar a ignorância, porque senão os vícios perduram necessariamente. Com efeito, ela é muito grande no homem, como afirma Aristóteles: "aquilo que os olhos dos morcegos são para o despertar do dia, a inteligência da nossa alma o é para as coisas que são as mais evidentes de todas." "Isso porque as coisas divinas superam de longe a capacidade dos homens, mas sobretudo porque o espírito abafado pelos pecados é escravo do sensível e não pode elevar-se para fazer um correto exame disso. O remédio não pode ser outro senão a revelação por Deus da

\footnotetext{
${ }^{88}$ Publílio Sírio, Sent. 645.

${ }^{89}$ O grego diz exatamente: o arrependimento é um demônio que salva, pois a razão tira as outras mágoas, e opera a conversão (metanóia) da alma ferida pela vergonha e que se pune a si mesma.

${ }^{90}$ Theodoret de Cyr e Justin.

91 "ce que les yeux des chauve-souris sont a l'éclat du jour, l'intelligence de notre âme l'est aux choses qui sont de toutes les plus évidentes." Aristóteles: Metafisica a1, 993b9. Esta imagem é retomada por Grotius $V R C$, II, 5:

"Semblable au hibou qui ne peut supporter les rayons du soleil, notre esprit ne pouvait s'arrêter dans la contemplation des choses divines sans en être presqu 'aussitôt ébloui." ("Semelhante a um mocho que não pode suportar os raios do sol, nosso espírito não podia parar na contemplação das coisas divinas sem por elas ficar deslumbrado.") A imagem de Aristóteles é retomada por São Tomas (Suma Teologica, qu ${ }^{\circ}$, art. 5) e Cajetan, que cita Leibniz, DP da Teodiceia $\S 48$.

Hugo Grotius - Meletius ou carta sobre aquilo que é objeto de acordo entre os cristãos. Tradução por Weslin de Jesus Santos Castro. Revisão por Dominique Marie Phillipe Geneviève Boxus
} 
verdade divina. Entre os povos reconhecedores do Cristo, os deuses falavam comumente de coisas humanas e apenas os homens falavam dos deuses, ao passo que é muito mais digno para Deus expor aos homens sua natureza e suas benfeitorias do que dar um conselho sobre o fim de uma guerra ou responder alguma questão semelhante. Era ainda uma enorme imprudência da parte do homem ousar afirmar alguma coisa sobre tão grandes assuntos sem alguma autoridade. A religião cristã tem então esse privilégio de apenas ela transmitir um ensinamento sobre Deus e sobre as coisas divinas, reconhecendo que ela o recebeu de Deus mesmo; sua palavra foi enunciada pelos mais santos profetas e em seguida pelo próprio $\theta \varepsilon \dot{o v v} \lambda o \gamma_{\gamma o \varsigma} \varsigma^{92}$, e a fim de que nos chegasse mais corretamente, essa palavra foi encerrada nos escritos.

Prova-se assim a verdade destes escritos: primeiramente, tanto na história quanto nos preceitos, não ensinamos nada que não seja digno de Deus, nada que não conduza aos melhores costumes, ao passo que, ao contrário, os poetas, os filósofos e todos aqueles que se apresentaram como mestres dos outros, ensinam muitas coisas indignas de Deus, coisas absurdas, e pior, distantes dos bons costumes; todas as suas histórias tratam de outros assuntos e negligenciam ordinariamente o que deveria ser seu principal exercício. Em segundo lugar, nos livros dos homens, mesmo aqueles que são membros de uma única seita, não se encontra nunca tão grande acordo. Os escritos sagrados dos Cristãos não são coerentes, eles podem também produzir testemunhas, fossem elas hostis, em muitas partes de seu discurso.

A Antiguidade acrescenta a verdade mais dignidade. Pois a antiguidade dos livros que constituem uma parte desta obra supera todos os livros humanos pelo conteúdo e pela composição. Varrão, apoiando-se na autoridade dos Anciãos, dividia a totalidade do tempo em "tempo desconhecido, tempo mítico e tempo histórico"93. Ele dizia que o primeiro tempo era aquele que precedia o dilúvio, do qual não se sabe nada. $\mathrm{O}$ segundo vai do diluvio à época troiana, em que reinaram as fábulas. No terceiro apareceu a luz da história. Mas esta história sagrada e verdadeira religa por um encadeamento de narrações o tempo que Varrão chama de mítico e aquele que ele confessa ser desconhecido. O primeiro redator deste volume foi Moisés, o mais antigo legislador segundo Diodoro; antes de sua época não pode haver nenhum escrito. Isso não é surpreendente, uma vez que os gregos - a partir dos quais toda a literatura se expandiu entre os outros povos - reconhecem terem recebido seu alfabeto dos Fenícios; ora,

\footnotetext{
92 O Verbo de Deus.

93 Varrão dividia o tempo em três grandes espaços: desconhecido, fabuloso e histórico. O primeiro vai do começo do mundo até o primeiro Dilúvio, o segundo do primeiro Dilúvio até a primeira Olimpíada, o terceiro da primeira Olimpíada até nós.)

Hugo Grotius - Meletius ou carta sobre aquilo que é objeto de acordo entre os cristãos. Tradução por Weslin de Jesus Santos Castro. Revisão por Dominique Marie Phillipe Geneviève Boxus
} 
o alfabeto fenício sendo o mesmo dos Hebreus, os Gregos deram a suas letras nomes fenícios ou hebraicos ${ }^{94}$.

Acrescentemos a isso ainda a união da maior simplicidade e da majestade de expressão. O reitor Denis Longin que escreveu $\pi \varepsilon \rho \imath$ v́$\psi o v \varsigma$, sobre o sublime, diz que esta expressão sublime (ou que convém às coisas divinas) foi muito bem observada pelo legislador dos judeus que ele chama: "um homem fora do comum, pois compreendeu e explicou a virtude divina ${ }^{95}$ como ela merecia, uma vez que no início de seu escrito sobre as leis ele diz: Deus diz: 'Que se faça a luz', e a luz se fez. 'Que se faça a terra', e a terra se fez." 96

Mas a simplicidade, além de ser uma grande parte da majestade, convém ainda aqui, a fim de que todos (mesmo os ignorantes) encontrem aí sem desvio o que basta para alcançar a salvação. Aqui, o homem não é conduzido ao conhecimento de Deus por perífrases nebulosas em meio à

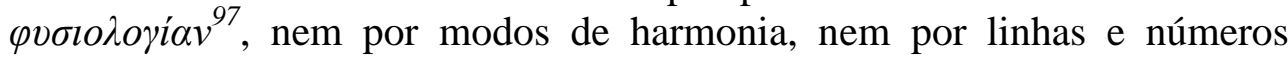
como em Pitágoras, Platão e outros; mas o que é necessário saber aparece claramente ao primeiro olhar em termos explícitos, de maneira que ninguém (sob a condição de ser dotado de razão) seja privado de uma verdade tão óbvia pela lentidão do espírito, pela obrigação de vir em socorro imediatamente de suas necessidades que a pobreza impõe, pelo sexo ou pela idade. E é um argumento muito notável o fato de que os outros meios não são verdadeiras vias rumo ao conhecimento de Deus, porque eles não são ordinariamente manifestos para todos. Mas Deus, que é o Deus comum a todos e o mesmo para todos, sem nenhuma dúvida instituiu para vir a ele um meio que seja igualmente acessível e fácil. Esta doutrina, em que existe uma regra certa da religião transmitida por Deus, está de acordo com sua bondade e convém muito para preparar e guiar os espíritos, a fim de evitar que os homens flutuem, incertos, entre tantas teses filosóficas divergentes e instituições dos povos, ou se abstenham sob este pretexto de toda religião.

Outra coisa que restaura o homem e o exemplo muito perfeito do Cristo. Os filósofos, sobretudo os estoicos, dizem que o homem não se serve menos dos exemplos de palavras, e frequentemente muito mais. Epicteto quer que olhemos em direção ao exemplo de Sócrates $^{98}$, quando deliberamos sobre aquilo que convém fazer sobre algum assunto. Sêneca

\footnotetext{
${ }^{94}$ Cf. VRC, I, 7. com referência a J.J. Scaliger, Animadversiones in chronologia Eusebii.

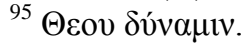

${ }^{96}$ Pseudo Login: De sublimitate, IX, 9.

${ }^{97}$ Ciência da natureza. Provável alusão aos filósofos pré-socráticos.

${ }^{98}$ Manuel: XXXIII, 12: “Quand tu vas rencontrer quelqu'un, surtout s'il est de ceux qui passent pour éminents, représente-toi ce qu'auraient fait dans cette circonstance Socrate ou Zenon, et tu ne seras embarrassé pour tirer de l'éventualité le parti qu'il convient." ("Quando encontrares alguém, sobretudo se este for daqueles que se passam por eminentes, imagine o que teriam feito Sócrates ou Zenão nesta circunstancia, e não ficarás embaraçado para tirar da eventualidade a parte que te convém.”)

Hugo Grotius - Meletius ou carta sobre aquilo que é objeto de acordo entre os cristãos. Tradução por Weslin de Jesus Santos Castro. Revisão por Dominique Marie Phillipe Geneviève Boxus
} 
para Catão ${ }^{99}$, alguns para Hércules, outros para Ulisses. Para cada um deles seria fácil lembrar muitos malfeitos, mentiras, trapaça, libertinagem, rebelião; também aquele que queria tomar sua vida por norma deveria errar frequentemente. Ao ver que eles pecaram em algumas coisas, pode-se perguntar se eles agiram bem em outras. Mas os cristãos propõem como modelo a imitar aquele que não pode ser acusado de nenhuma culpa. Aquele cuja vida inteira é plena, não de violências e combates como Maomé e o Messias esperado pelo Judeu, mas de piedade, de caridade, de mansuetude, e de paciência. E para que as penas - que acompanham geralmente aqueles que seguem a virtude - não nos assustasse, ele mesmo deu o exemplo das penas e da virtude, e em contraponto a suprema recompensa e felicidade: crucificado depois de ultrajes muito atrozes, tendo suportado pacientemente a morte, ele voltou de novo à vida; depois ele subiu ao céu e daí mesmo, ele se manifestou pela força de suas obras admiráveis como rei e senhor de todas as coisas, a fim de que todos aqueles que marcharem sobre seus passos considerem que eles participaram de uma tão grande glória. Cada um compreenderá facilmente o quanto esta maneira de mover os corações e eficaz. Mas fora da religião cristã, nenhuma outra se dispõe a isso.

O terceiro e o maior remédio é a força escondida de Deus, ou seja, o Espírito que excita o coração humano viver retamente, que o incita a isso, o conduz e o confirma. É uma questão entre os filósofos saber "se se torna bom por um favor divino."100 A maioria sustenta com argumentos manifestos que os homens se tornam bons por causa favor divino, porque é digno de Deus dar o melhor, e que o homem por sua própria realidade cai nos vícios, tem necessidade de ajuda para atingir a virtude. Assim Sêneca: "Deus vem em direção aos homens, muito mais, porque ele é de mesma natureza, ele nos homens, sem Deus, nenhum espírito é bom." ${ }^{101}$ Mas não se insiste nisso tanto quanto seria preciso. Daí vem que os homens não esperam tão seriamente de Deus o que lhe seria mais necessário; a religião cristã com uma moderação muito salutar, presto a Deus pleno louvor para a regeneração do homem, com esta reserva que não se pensa que o bem se faça apesar de si, mas voluntariamente. Assim evitam-se dois perigos: o desespero em razão de sua fraqueza, a que presta socorro a confiança na ajuda de Deus, de tal forma que se pode dizer com Sêneca aqueles que abandonam: "Não queremos, eis a verdadeira razão, não podemos, eis o pretexto." 102 Por outro lado, orgulho e confiança em si são refreados:

${ }^{99}$ Ep. 95:72; 104:21.

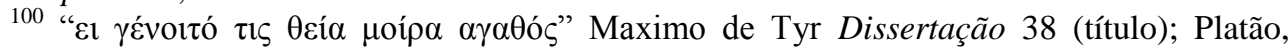
Menão, 99e e Sêneca Ep. 41, § 2: "Homme de bien, aucun ne l'est en vérité sans l'intervention d'un dieu." ("Homem de bem, nenhum o e de fato sem a intervenção de um deus.") A, بoípa, moira, e a sorte, a parte do destino garantida a cada um pelos deuses.

101 "Dieu vient vers les hommes, bien plus, car il est de même nature, il vient dans les homes; sans Dieu nul esprit n'est bon." Sêneca Ep. 73, 16.

102 "On ne veut pas, voilà la vraie raison, on ne peut pas, voilà le prétexte." Sêneca Ep. 116,8 .

Hugo Grotius - Meletius ou carta sobre aquilo que é objeto de acordo entre os cristãos. Tradução por Weslin de Jesus Santos Castro. Revisão por Dominique Marie Phillipe Geneviève Boxus 
mostra-se ao homem sua aflição quando se lhe ensina que a virtude — sem a qual ele não é nada - ele não a tem por si mesmo, mas recebe de Deus como um dom, de encontro a essas palavras muito orgulhosas dos Estoicos: "É estúpido esperar receber uma alma boa enquanto tu podes obter isso por ti mesmo." "103 Tais são os princípios que concernem ao próprio homem.

Para os assuntos humanos uma única coisa é suficiente: além da virtude, a religião; o resto é $\alpha \delta l \dot{\alpha} \varphi \rho \rho \alpha^{104}$, para o fim supremo do homem. Os cristãos não brigam a respeito das palavras e não se opõem como fazem os Estoicos, naquilo que a vida, a saúde, o saber, a honra, as riquezas sejam chamadas de bens; naquilo que a morte, as doenças, a falta de saber, a desonra, a pobreza, sejam chamadas de males. Ou melhor, eles pensam que é útil que estes termos conservem seu uso recebido a fim de que o homem saiba melhor que ele deve render graças a Deus pelos primeiros e saiba por outro lado que os últimos são punições dos pecados ou experiências de resistência. Para pensá-lo realmente é preciso que o homem se alegre com os primeiros enquanto condizentes a natureza, e sofra com os segundos que são contrários a natureza. Ao mesmo tempo, é preciso admitir isso: nenhum dos dois tipos está no direito ${ }^{105}$ de dar ou tirar o bem supremo e último, mas eles podem se tornar matéria das virtudes ou dos vícios segundo o que nós usamos disto bem ou mal. Isso é o bastante para os princípios.

Para chegar aos preceitos, vale a pena olhar o que pensaram sobre isso, em resumo, mesmo aqueles que professavam outra religião. Estrabão chama os antigos Judeus - de quem os cristãos são herdeiros que professavam princípios semelhantes ${ }^{106}$ - de "homens tementes a Deus e sábios", ele diz sobre os sucessores de Moisés: "seus sucessores... durante certo tempo detiveram-se naquilo que ele havia instituído, sendo verdadeiramente homens justos e piedosos." Falando deles, Trogue Pompeu, ou Justino que o cita, diz que: "sua justiça era confundida com a religião." Plínio diz sobre os cristãos: "eles têm o costume de se comprometer via juramento não a perpetrar algum crime, mas a não cometer delito, depredação, adultério, não faltar com sua promessa, não recusar restituir um deposito." ${ }^{107}$ Amâmio Marcelino: "a profissão de fé cristã não ensina nada que não seja justo e bom." Mas analisemos de mais perto estes preceitos segundo suas partes.

Logo, há deveres em relação a Deus, aos homens e aos assuntos humanos. Devem ser tratados primeiramente os deveres para com Deus,

\footnotetext{
103 "Il est stupide d'espérer recevoir une âme bonne alors que tu peux l'obtenir de toimême." Sêneca Ep. 41,1.

${ }^{104}$ Indiferente. Adiaphora é um termo técnico da filosofia estoica.

105 Jus.

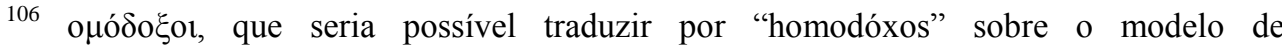
"heterodoxos", designa aqueles que professam princípios doutrinais semelhantes.

107 "ils ont coutume de s'engager par serment non à perpétrer quelque crime, mais à ne pas commettre de larcin, de brigandage, d'adultère, ne pas manquer à leur promesse, ne pas refuser restituer un dépôt." Plinio Ep. X, 96, 7.

Hugo Grotius - Meletius ou carta sobre aquilo que é objeto de acordo entre os cristãos. Tradução por Weslin de Jesus Santos Castro. Revisão por Dominique Marie Phillipe Geneviève Boxus
} 
como o fazem os cristãos. Sobre este ponto não se pode condenar os anciãos que, quase todos, escreveram sobre os deveres e a moral e entre os quais esta parte está, ou muito totalmente silenciada enquanto, que é a mais importante, ou é tratada apenas como parte da obediência devida as instituições civis. A tal ponto que Varrão e outros não se envergonham em escrever que, por respeito às leis, seria preciso conservar as religiões, mesmo falsas assim como seus deuses. O Senado romano se arrogou o direito de fazer os deuses que ele queria. Que mais senão suprimir a religião institucionalizando-a? Os próprios filósofos pensam que eles não falavam, enquanto que a verdade deveria lhes ser mais santa do que tudo. O ensinamento cristão vence através disso todos os filósofos e legisladores, porque ele ordena aos homens e em todo tempo, o culto, o amor e a veneração a Deus. Ele o faz sempre, e a isso ele relaciona tudo.

As regras prescritas em relação a Deus são por um lado internas, por outro, externas. Os preceitos internos são aqueles que movem a alma, entre os quais dominam estes aqui: acreditar em Deus e invocá-lo. Crer em Deus é seguramente difícil para aqueles que ignoram o que Deus diz; mas para os cristãos que conservam a própria palavra de Deus é fácil. Nos já tratamos disso.

Entretanto, invocar Deus é algo extremamente perigoso, nos dizeres de Platão, que confessava não saber o que ele devia pedir na prece. ${ }^{108}$ Os poetas mostram que muitos infortúnios aconteceriam aos homens se suas preces fossem atendidas. Os cristãos aprendem antes de tudo a rezar, contra a impiedade de alguns ${ }^{109}$ (filósofos apenas no nome) que negam que se deva rezar a Deus. Em seguida, de encontro à ignorância comum, eles aprendem aquilo por o que devem orar: aquilo que visa à gloria e à honra de Deus, para que ele seja honrado e obedecido em tudo; enfim, naquilo que lhes concerne eles mesmo: para esta vida, nada além das necessidades da natureza e para a outra, os socorros que são o perdão das culpas e a proteção contra estas.

Entre as ações externas que se reportam a Deus, algumas são proibidas, outras ordenadas. Entre as proibidas algumas versam sobre palavras, e outras sobre os atos. Tratando-se de palavras, é-nos proibido dizer o nome de Deus de maneira ímpia, levianamente, ou sem respeito, o que é muito mais exigente do que as proibições dos outros que se limitam ao perjúrio. Mas, o quanto a maioria dos homens errou outrora sobre esse ponto, uma vez que seus livros estavam repletos de inventivas muito duras contra os deuses. No que concerne aos atos, à primeira proibição é algo que quase todos os povos reconheceram outrora: o fato de se representar Deus por uma imagem. Os platônicos brigaram para saber "se seria preciso erigir estátuas dos deuses." 110 Pitágoras entre os filósofos e Numa entre os

\footnotetext{
${ }^{108}$ Platão, Eutyphron, 14d-15c.

109 Alusão aos Epicureus, anteriormente qualificados no $\S 18$ como filósofos fictícios.

${ }^{110}$ Máximo de Tyr: título da dissertação 8.
}

Hugo Grotius - Meletius ou carta sobre aquilo que é objeto de acordo entre os cristãos. Tradução por Weslin de Jesus Santos Castro. Revisão por Dominique Marie Phillipe Geneviève Boxus 
legisladores $^{111}$, proibiram o uso de imagens. Eurípedes e Sêneca ${ }^{112}$ as condenam também. O imperador Adriano construiu templos desprovidos de imagens. Tácito deu razão a isso no que se refere às instituições judaicas: "os Egípcios veneravam a maioria dos animais e suas estátuas, os Judeus compreendem por um único espírito uma única divindade: para eles, é uma impiedade pintar imagens dos deuses sob a forma humana em materiais perecíveis; esta divindade suprema é eterna, imutável e imortal. Por isso, não havia estátuas nas suas cidades, muito menos nos seus templos." ${ }^{\text {"13 }}$ Não convém a um Deus incomparável ser comparado a qualquer coisa e o homem que pensa em Deus deveria desviar não apenas os olhos e os sentidos, mas também a alma de toda realidade material e sensível, na medida do possível, para compreender esta natureza extremamente simples e que ultrapassa toda natureza.

A religião cristã nos dá ainda esta recomendação: não prestar a Deus um culto demasiadamente trabalhoso e com inumeráveis ritos, e, a esse respeito, ela supera não apenas as religiões dos povos antigos que forjavam numerosos cultos não ordenados por Deus - e que logo não lhe eram agradáveis - mas, ainda, a religião judaica cheia de cerimônias onerosas e irritantes. Além de que isso deixa um grande lugar para a liberdade e constitui uma benfeitoria insigne a Deus, nos lembra também que o principal culto a Deus reside no espírito.

A principal regra externa concernente ao culto a Deus e frequentar estas assembleias instituídas em vista do culto divino, para onde se reportam as palavras de Deus, em que se ancoram os homens a piedade e em que se sustentam as preces públicas. Pois, se Cícero, estando de acordo com os filósofos, teve razão em dizer: "Não existe nada sobre a terra, com efeito, que o primeiro dos deuses (aquele que rege o mundo) prefira a estas assembleias e sociedades humanas regidas pelo direito" "i14 ; que se pode pensar destas assembleias que se mantêm para permitir aos homens religiosos em grande número prestar um culto a Deus com zelo igual e sentimento comum? Pois, se Deus aprecia o bom acordo dos homens e o culto, o quanto ele deva apreciar o bom acordo dos homens no seu culto! Para uma observância mais fácil, reserva-se uma parte determinada do tempo para o culto divino e para realizar assembleias: todos os sete dias, segundo um equilíbrio muito sábio entre as numerosas distrações que provêm das ações humanas e o esquecimento prolongado da religião. Se Sêneca e outros compreendessem isso, eles não teriam chamado de preguiça o sabbat dos Judeus, pois não há tempo que seja mais justificado que aquele consagrado ao mestre do tempo. Aqui é necessário observar bem isso: entre os povos desconhecedores do Cristo aconteciam reuniões para as coisas

\footnotetext{
${ }^{111}$ Plutarco Num. 65. Cf. DGP, II, XX, 45, § 2.

112 Qu. nat. 8, 3. "Effugit oculos: cogitatione visendus est (deus)".

113 Tácito: Hist. V, 5. Texto já evocado no $\$ 22$.

${ }^{114}$ Cícero Rep. VI, 13 (sonho de Scipião).
}

Hugo Grotius - Meletius ou carta sobre aquilo que é objeto de acordo entre os cristãos. Tradução por Weslin de Jesus Santos Castro. Revisão por Dominique Marie Phillipe Geneviève Boxus 
sagradas, sem nenhuma instrução do povo, para o espetáculo e a pompa exterior, e isso não era feito pelos sacerdotes, mas sim pelos filósofos que transmitiam os preceitos concernentes às coisas divinas e à regra de vida. Vê-se então que a religião deles era vã e fútil. Mas, entre os cristãos, o principal objetivo de uma reunião é ouvir a vontade de Deus transmitida por um intérprete.

Em seguida, vêm os signos, nem numerosos nem complicados, mas muitos eficientes para mover os corações. Assim, conveio a Deus prestar socorro a tudo o que concerne a nossa fraqueza, uma vez que geralmente "aquilo que passa pelo ouvido faz efeito mais lentamente do que aquilo que e transmitido a olhos fieis."

A princípio, quase todos os povos fizeram uso de agua para as purificações:

\footnotetext{
"Recebe, o Pai, os objetos sagrados e os penates ${ }^{116}$ paternos / para mim, regresso de uma tão grande guerra e de um massacre recente / seria sacrilégio tocar nisso, sem primeiro ter me lavado na água viva do rio." 117
}

Os cristãos se purificam também com água, e, para que fique claro que a cerimônia não é vã, resume-se a religião em muito poucas palavras, invocando o Pai que dá a vida, o Filho que concede o perdão, e o Espírito que confere a santidade. Nos livros sagrados de Mitra, lemos que se fazia uso de pão e de vinho, e dentre os Mistérios gregos, os principais ritos sagrados em honra a Ceres e Liber ${ }^{118}$ lembram a origem do pão e do vinho. Seguramente, essas duas coisas são os presentes mais importantes de Deus nesta vida. Porém, da mesma forma que a religião ensina que essa vida conduz a outra a vir, da mesma forma os cristãos representam por meio desses presentes a memória de recompensas bem maiores. Porque, já que o verbo de Deus assumiu por nossa causa, o corpo e o sangue humanos, para se tornar vítima por nós e nos unir a ele, convém certamente que esse corpo e esse sangue não sejam menos o alimento das almas do que o pão e o vinho o são do corpo e do sangue. O quanto isso está afastado dos mistérios dos povos primitivos nos quais há muita obscenidade, frequentemente jogos públicos, todos tais que os próprios sacerdotes não possam justificar sua conveniência?

\footnotetext{
115 “ce qui passe par l'oreille fait de l'effet plus lentement que ce qui est transmis à des yeux fideles." (Horácio, Arte poética, $180,11^{\circ}$ preceito).

${ }^{116}$ Deuses do lar, entre os romanos e etruscos. (N.T.)

117 "Toi, Père, reçois les objets sacrés et les pénates paternels / pour moi, revenu d'une si grande guerre et d'un récent massacre, / il serait sacrilège d'y toucher tant que je ne me serai pas lavé dans l'eau vive du fleuve." (Virgilio, Eneida, II, 717-20.)

${ }^{118}$ Ceres é a divindade da agricultura e simboliza o pão, Liber é a divindade do vinho, confundido com Baco.

Hugo Grotius - Meletius ou carta sobre aquilo que é objeto de acordo entre os cristãos. Tradução por Weslin de Jesus Santos Castro. Revisão por Dominique Marie Phillipe Geneviève Boxus
} 
Mas não é preciso conservar um erro largamente difundido: a estrita observância das cerimônias prepara a felicidade da outra vida, pois não há nada melhor para desviar dos bons costumes. Assim Sófocles: "Três vezes bem-aventurados aqueles que migram ao Hades depois de terem visto esses mistérios. Para eles apenas a morte da vida, para os outros, ela não é nada mais que uma imensa infelicidade."119

Dizem que esses versos encheram de desespero milhares de não iniciados. Mas Diógenes fez uma objeção a alguém que defendia semelhante tese sobre o caso de Patecião, um ladrão; ele perguntou se seria crível que este fosse mais bem tratado em outra vida do que Epaminondas - que era muito honrado por sua pátria e por seus concidadãos, porque Patecião era um iniciado, ao passo que Epaminondas não o era. Os cristãos estão bastante afastados disso, acreditando não somente que as leis rituais sejam suficientes, mas ainda que elas sejam bem inferiores em dignidade ao que prescrevem os deveres da caridade. Passemos a isso agora.

Dentre os deveres em relação aos homens, alguns concernem àquilo que o homem deve aos outros e outros àquilo que ele deve a si mesmo. Os deveres em relação a outrem são devidos à humanidade ou à ordem social. Em relação à humanidade, em uma palavra, a amizade é indispensável, em razão do parentesco natural e de imagem de Deus. Nesse ponto, a piedade crista exige mais, ou dá prescrições mais claras que as outras seitas. Com efeito, a maioria considera apenas as ações externas e não chegam aos corações. Nesse respeito escrupuloso e nessa observância externa dos ritos, os fariseus punham confiança em sua salvação de maneira supersticiosa e ímpia. Mas os cristãos reclamam a caridade de coração e manifestada pelos atos. A vida, a liberdade, a honra, as riquezas do próximo devem ser estimadas como se fossem nossas. Quem atentou contra isso, não só em prática, mas em palavras, e mesmo apenas em pensamento, recebe diante da face de Deus a acusação de homicídio e roubo; o que está de acordo ainda com esta regra curta, clara, louvada pelo imperador Adriano: "Não faça a outrem aquilo que não desejarias que te fizessem."

Portanto o cristão, diferentemente de todos os povos, não considera como perdoáveis as depredações que se escondem atrás do nome de guerra, ou os roubos que se insinuam sob o titulo de empréstimo com juros. Ele não julga as coisas pelas palavras ou pela frequência dos casos, mas pelo seu conteúdo. Assim então, mesmo reconhecendo uma amizade própria entre os que confessam o zelo pela mesma piedade, entre os quais vários laços fazem com que a afeição também deva ser maior e com mais inclinação, ele não exclui, entretanto, nenhum homem de seu amor, ele não separa, como Aristóteles, os Bárbaros dos Gregos, como outra espécie de seres animados, e não os submete às injustiças, ou pior, à servidão. Mas ele acredita que

119 "Trois fois bienheureux ceux qui migrent vers Hades après avoir vu ces mystères. Pour eux seuls, la mort donne de vivre, pour les autres, elle n'est rien qu'un immense malheur." (Fragmento 753. Plutarco: Mor. 21F.)

Hugo Grotius - Meletius ou carta sobre aquilo que é objeto de acordo entre os cristãos. Tradução por Weslin de Jesus Santos Castro. Revisão por Dominique Marie Phillipe Geneviève Boxus

Griot - Revista de Filosofia, Amargosa, Bahia - Brasil, v.10, n.2, dezembro/2014/www.ufrb.edu.br/griot 
todos esses são também homens por natureza e, portanto, devem ser considerados como irmãos. Nesse ponto os judeus se enganaram tragicamente, outrora e ainda agora, como o indicam bem estes versos de Juvenal: "Não mostrar o caminho, exceto a quem venera a mesma religião, conduzir os únicos circuncisos a fonte procurada." ${ }^{20}$ E Tácito: "Entre eles [há] uma fidelidade tenaz, a prontidão do socorro, mas um ódio implacável em relação a todos os outros povos."

Ainda mais, o cristão considera como um homem aquele que lhe prejudicou. Aristóteles ${ }^{122}$ e Cícero louvam a vingança como própria da natureza. E melhor, como afirmam os platônicos e estoicos, proibir fazer a injustiça. "A vingança", como diz Sêneca, "difere da injúria apenas no tocante à ordem dos fatos." ${ }^{23}$ A ligação entre a imagem divina e a natureza é demasiada forte para que uma ação qualquer do homem possa rompê-la.

$\mathrm{O}$ homem deve se comportar em relação ao homem da mesma maneira que ele deseja que Deus se comporte em relação a ele. Ele o quer clemente e pronto para perdoar. Por isso "perdoa-se facilmente quando se precisa de perdão." ${ }^{124} \mathrm{Na}$ verdade, segundo os princípios dessa religião, é muito pouco não prejudicar, é preciso prestar serviço da maneira como se pode, compadecer-se por inteiro das infelicidades dos outros, dividi-las. Os filósofos escreveram muito sobre as boas ações, mas eles omitiram o essencial: certos homens nos são recomendados pelo único fato de serem infelizes. A nudez, a fome, a sede, a doença, a prisão, o exílio, todos esses são títulos que por natureza exigem de nós algum cuidado. Esse fato foi ocultado por alguns filósofos que tratam dos deveres e ele foi até mesmo denegrido; e, no entanto, é muito agradável a Deus e a humanidade a palavra $\dot{\lambda} \varepsilon \mu_{0} \sigma v_{v} \eta^{125}$. O primeiro momento da compaixão é tratar com benevolência aqueles que estão desorientados em matéria de piedade e de costumes. Dentre as coisas abomináveis aos atenienses estava a de "não mostrar o verdadeiro caminho." Essa bondade e essa caridade em relação a todos os homens, mesmo aos que nos são hostis, é distante das instituições de diversos povos, a exemplo dos espartanos outrora, cujo todo o ensinamento preparava para os homicídios e para os furtos, mas não para o cultivo da paz.

A ordem sobre a que se estabelecem as questões humanas é dupla: a família e a república. Nos dois casos o cristianismo prescreve o que se pode dizer ou pensar de melhor. A princípio, ele não autoriza as uniões ilícitas,

\footnotetext{
120 "ne pas montrer le chemin, sauf à qui venère la même religion / Conduire les seuls circoncis à la source recherchée." (Juvenal: Satiras, 14: 103-4.)

121 "Entre eux une fidelité tenace, la promptitude du secours, mais envers tous les autres peuples une haine implacable." (Tácito: Hist. , V, 5.)

${ }^{122}$ Aristóteles: E. N. IV, 11, 1126a7-9.

${ }^{123}$ Sêneca: De ira, II, 32, § 1 .

124 "qu'on pardonne facilement quand on a besoin de pardon." (Sêneca: Agamenon, 267.)

125 A compaixão.

Hugo Grotius - Meletius ou carta sobre aquilo que é objeto de acordo entre os cristãos. Tradução por Weslin de Jesus Santos Castro. Revisão por Dominique Marie Phillipe Geneviève Boxus
} 
mas as une pelos laços do matrimônio para que o chefe de família se preocupe com os seus, para que seus filhos sejam posse dele; o que está bem distante das extravagâncias indignas de filósofos, consideradas assim por Sócrates e Platão, que propõem na melhor república a partilha de tudo, até mesmo das esposas. Como se a natureza não ensinasse que se se ocupa melhor de questões próprias e pessoais do que aquelas que são colocadas em comum; como se o acordo de todos os povos, exceto de um pequeno número estranho a toda prática humana, não mostrasse suficientemente o quanto o matrimonio é algo sagrado.

Os cristãos pensam igualmente que não é permitido casar-se com qualquer pessoa, como fazem os persas com suas mães, os reis da Ásia e os atenienses com suas irmãs. Para evitar a consanguinidade, eles distinguem por limites fixos os que são da mesma linhagem - aos quais se devem respeitar - e aqueles com os quais se pode casar; eles estendem dessa forma os laços de afeição, multiplicando-os. Como os romanos, eles seguem muito bem nesse ponto a natureza - da qual se separaram a maioria dos povos outrora e todos os maometanos hoje - de maneira que o homem tenha apenas uma esposa. Logo, sobre os primeiros afirmou-se sem injustiça que: "Ignoramos a Vênus bárbara que, cega como bestas selvagens, poluiu pelo numero de esposas as leis e os juramentos do casamento, desvelando segredos abomináveis da alcova entre mil jovens mulheres?" 126

Mas Eurípedes segue a natureza: "Não é bom que um homem, que não deseja viver vergonhosamente, segure as rédeas de duas mulheres. Que ele vele sobre um único leito e preze carinhosamente a mulher amada." ${ }^{127} \mathrm{E}$ Tácito, ao tratar dos germanos: "Há um aspecto de seus costumes que não se poderia louvar em demasia: eles são praticamente os únicos entre os bárbaros que se contentam com somente uma esposa." 28 Seguramente, o amor, que durante o casamento deve ser o sentimento humano mais forte, perece se ele se dispersar; e o cuidado da casa - que por natureza pertence às mãos da mulher - só pode ser exercido corretamente por apenas uma.

Dessa forma, a regra dos cristãos é ter casamentos indissolúveis, sem divórcios. A maioria dos povos do Oriente e mesmo os Judeus tiveram uma prática oposta: nesse ponto, deve-se louvar praticamente só os romanos, porque eles conservaram intacta a fidelidade matrimonial durante seiscentos anos. Não há nada de tão contrário à suprema amizade, que deve reinar entre cônjuges, quanto a possibilidade de rompê-la. E a incumbência comumente

\footnotetext{
126 “Ignorons-nous la Vénus barbare qui, aveugle à la manière des bêtes sauvages, a pollué par le nombre d'épouses les lois et les serments du mariage, en dévoilant des secrets d'alcove abominables entre mille jeunes femmes?" (Lucain Pharsale: VII, 397-401.)

127 "Il n'est pas bon, / qu'un homme tienne les rênes à deux femmes / Qui désire ne pas vivre honteusement, qu'il veille sur un seul lit et chérisse tendrement la femme aimée." (Eurípedes Andrômaca: 177-180.)

128 "Il y a un aspect de leurs moeurs qu'on ne saurait trop louer: presque seuls parmi les barbares, ils se contentaient d'une seule épouse." (Tácito: Germânia: 18.)

Hugo Grotius - Meletius ou carta sobre aquilo que é objeto de acordo entre os cristãos. Tradução por Weslin de Jesus Santos Castro. Revisão por Dominique Marie Phillipe Geneviève Boxus
} 
imposta pela natureza, à educação dos filhos, deve também ser preenchida por ambos. Que são esses divórcios senão adultérios disfarçados? "Casar-se tantas vezes e permanecer adultero legalmente (...) a prostituta assumida me escandaliza menos." "29 Há ainda obrigações dos pais, dos filhos e dos esposos entre eles: aos primeiros o dever de comandar com doçura, aos segundos, o de obedecer com constância, e para todos o de concordar igualmente.

No que se refere à república, às leis dos cristãos são tais que os seus exemplos mostram bem que os próprios homens são ao mesmo tempo virtuosos e excelentes cidadãos. Aos olhos dos cristãos são sagrados não apenas os magistrados da plebe, mas sim todos os magistrados, pois seu poder deriva de Deus. Ao dizer isso não se incita o povo, com propostas severas dos estoicos, a odiar os reis e governantes; não se ensina a secessão, ordena-se a cada um a satisfazer-se com seus governantes, a pedir por meio de suas preces os melhores dirigentes para a república, a tolerá-los como são, a suportar as incumbências prescritas, a obedecer com diligência suas ordens (ainda que sejam pesadas) sob a condição de estas não violarem os preceitos divinos: essa doutrina é seguramente muito útil para manter as cidades em seu estado, sobretudo porque os dirigentes são claramente advertidos de que o comando supremo e o mais próximo daquele de Deus não escapa a vigilância divina.

As obrigações do homem em relação a si mesmo se remetem umas a ele próprio, outras, àquilo que depende dele. A ele mesmo, o dever de preservar com todo seu cuidado a vida, a conservação de si e a saúde. O cristão não tem nenhuma dúvida quanto àquela controvérsia (levantada há muito tempo por Platão) a respeito da licitude do ato de se suicidar: ele se pronuncia contra Catão. Porque para todos é normal se proteger, e o homem não foi colocado nesse mundo por acaso, mas por ordem divina, como num posto militar do qual não permitido sair sem convidado para isso. Que ele suporte as provações, a servidão, em vez de atestar por meio de um homicídio sua incapacidade de viver. "Comporta-se com mais coragem aquele que sabe suportar o infortúnio.,"130

Mas quando a morte se apresentar, que não abandone de má vontade o corpo, um domicilio querido, mas que ele o faça com a esperança de uma grande recompensa. " $E$ covarde reter com avareza a vida que se deve render." $" 131$

O cristão não pensará jamais que a morte é um mal sem acreditar que o seu pecado é um mal ainda maior; ele não comprometerá a vida em

\footnotetext{
129 "se marier si souvent c'est être adultère légalement / la franche prostituée me choque moins." (Marcial, Epigramas: VI, 7, 5-6.)

130 "Il se comporte avec plus de courage, celui qui sait supporter d'etre malheureux." (Marcial XI, 56, 16.)

131 "Il est lâche de retenir avaricieusement la vie qu'il faut rendre." (Lucain Pharsale, I, 462.)

Hugo Grotius - Meletius ou carta sobre aquilo que é objeto de acordo entre os cristãos. Tradução por Weslin de Jesus Santos Castro. Revisão por Dominique Marie Phillipe Geneviève Boxus
} 
detrimento da virtude, mas em vez de aceitar qualquer coisa proibida por Deus, irá sobre a cruz e nas chamas. Um só ano trouxe tantas vezes mais exemplos dessa autêntica coragem entre os cristãos (submetidos aos inimigos de sua religião) que no decorrer de todos os séculos ela não foi vista entre os membros de outras seitas. E não sem razão, pois apenas o cristão dispõe de seguras consolações diante da morte. Como os filósofos não as têm, eles inventam falsas, que por essa razão não penetram no coração. Em que me ajudará se me disserem que não há nada depois da morte, uma vez que voltar ao nada é muito infeliz e certamente contrário á natureza? Para que serve me dizerem que a morte restabelece a natureza, não com uma punição, já que o mal, qualquer que seja a causa de onde ele venha, não deixa de ser um mal?

A respeito dos homens, encontram-se coisas, ações, palavras, pensamentos: coisas como honras, riquezas, prazer. Ao cristão é ordenado ter por suspeito o desejo de honra e glória, enquanto corruptor da virtude que perece se ela preferir qualquer coisa a Deus. Se ele os obtiver, entretanto, não deve repudiá-los, mas deve reportar toda a honra a Deus, doador dos bens, e de moderar-se a si mesmo, consciente de sua fraqueza, a fim de não ficar inclinado aos vícios. A maioria desconheceu tanto esse

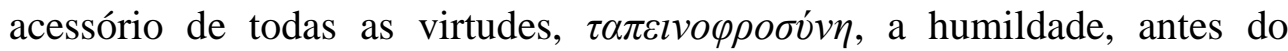
ensinamento cristão, que quase seu nome jamais aparece entre elas.

A respeito das riquezas, a $\varphi \imath \lambda o \chi \eta \mu \alpha \tau i \alpha$ é proibida, o amor imoderado das riquezas se desenvolvendo sem limites, tornando-se um inimigo da tranquilidade e torturando o coração. Ao contrário, ordena-se a cada um tentar obter por meios honestos o que é necessário, para si e sua família. Se Deus lhe obteve em demasia, ele não lançará no mar os meios de viver, à maneira estúpida de alguns filósofos ${ }^{132}$, mas ele diminuirá com sua abundância a indigência de outros. Se, no entanto ele [Deus] o cumular de ignomínia e pobreza, que ele os suporte corajosamente, já que não pode curá-los, e isso sem fazer como se não lhe dissesse respeito - porque essa incapacidade não é uma consolação - o que é contrário à verdade da natureza; pois ao sentir esses fardos que Deus lhe faz carregar, ele corrige seus vícios, exerce suas virtudes, como se fossem medicamentos desagradáveis ao gosto, mas de eficácia salutar, ou combates difíceis, mas que conduzem a recompensas.

O reino do prazer consiste, sobretudo, em manjares, bebida, sexo, aos quais se podem acrescentar o lazer e sono. Toda comida e toda bebida foi dada por Deus para consumo humano, o cristão o reconhece facilmente. Por conseguinte, ele não cai na servidão judaica pela discriminação da comida, e não condena no vinho (como os maometanos) o criador do vinho, mas aprende a usá-lo moderadamente e sobriamente, não segundo a medida

${ }^{132}$ Aristipo (Cf. Diógenes Laercio: II. 77) e Crates de Tebas (Cf. Filóstrato, Vida de Apolônio de Tiana, I, 13-15).

Hugo Grotius - Meletius ou carta sobre aquilo que é objeto de acordo entre os cristãos. Tradução por Weslin de Jesus Santos Castro. Revisão por Dominique Marie Phillipe Geneviève Boxus 
do desejo ou do luxo, mas conforme aquela que satisfaz a natureza, banindo, sobretudo, a embriaguez, enquanto desperdício de algo bom e inimiga da razão e da saúde. Entretanto, houve experiências de vícios que foram muito célebres outrora entre os gregos, chamadas orgias.

O cristão põe outra prescrição acima dessa moderação cotidiana em matéria de alimentação. Quando o espírito se eleva na oração e o corpo enseja fazer outra coisa, ele diminui o peso e as forças desse corpo e recorre aos jejuns, não como algo por si mesmo agradável a Deus, mas como necessário ao homem; os filósofos não trataram disso, mas povos o praticaram nos seus ritos, por costume, não por evidência racional.

Os prazeres do amor são proibidos fora do casamento. A cegueira de todos os filósofos e legisladores sobre esse ponto é muito surpreendente. "Que um homem de alguma notoriedade saia do bordel... Parabéns! Boa sorte! diz-lhe o discurso divino de Catão." "133 Epicteto fala melhor sobre isso: "Antes do casamento, abstenha-te dos prazeres amorosos."134

A própria palavra tem sua lei, que se resume em não se desviar da verdade. A defesa desta é fácil, por exemplo, contra Platão que concordou com o direito de mentir de certos homens ${ }^{135}$. Mas a palavra foi dada aos homens por Deus para estreitar a sociedade, quando os homens se comunicam e transmitem uns aos outros seus pensamentos. Uma vez concedida essa licença, ela desfaz todo limite e suprime o que ha de mais útil nas questões humanas: que o homem acredite no homem.

Em relação imediata com essa regra está a obrigação de cumprir suas promessas. Esta exigência é para a religião cristã muito mais sagrada do que para aqueles que escreveram sobre os deveres, como Panécio, e Cícero que o imita; com efeito, para esses autores é preciso sustentar seu discurso para com um inimigo politico, mas não para com um ladrão ou um tirano, pois conforme o que dizem eles, com esses tipos de indivíduo não há sociedade de direito humano. Esse argumento é evidentemente falso. Porque o engajamento dos pactos não visa aos homens, mas a Deus, que ama tanto a verdade que quer que se diga o que se pensa e se façaa o que se diz. Todos os homens devem então manter sua palavra em todos os seus pactos, a menos que alguém tenha prometido algo proibido por Deus, pois isto não dependia de seu poder antes de prometer.

Os pensamentos tem também sua regra. Não é uma lei dos homens, mas de Deus, a quem se deve também a bondade interior e sem testemunha.

\footnotetext{
133 "Qu'un homme de quelque notorieté sorte du bordel, bravo, bon courage, lui dit le propos de Caton.” (Horácio, Sátiras, I, 2, 31-32.)

134 “Avant le mariage, abstiens-toi des plaisirs de l'amour.”(Epitecto: Manuel. 33,8)

135 Platão Rep. 382c: "Mas no que concerne à mentira em palavras, quando e a quem ela é suficientemente útil para não mais se tornar odioso? Não seria para com os inimigos e aqueles que chamamos de amigos, quando o furor e a demência os levariam a más ações?" ["Mais pour le mensonge en paroles, quand et a qui est-il assez utile pour n'être plus haissable? N'est-ce pas a l'égard des ennemis et de ceux que nous appelons amis quand la fureur ou la démence les porterait à quelque mauvaise action?" (trad. Chambry)]

Hugo Grotius - Meletius ou carta sobre aquilo que é objeto de acordo entre os cristãos. Tradução por Weslin de Jesus Santos Castro. Revisão por Dominique Marie Phillipe Geneviève Boxus
} 
Essa lei diz que não se deve pensar naquilo que é proibido fazer. Isso consiste em desviar a fonte do mal, cortando sua raiz. Porque nós o reconhecemos com Sêneca: "o ladrão é ladrão antes mesmo de sujar suas mãos. A maldade se exerce e se faz ver por sua operação, mas ela não começa aí."136

É uma regra comum a todas as regras que não basta fazer aquilo que é ordenado, se não o fazemos apenas porque é ordenado. Algumas pessoas cumprem os mandamentos, mas para agradar aos homens, para ter boa reputação; estes nós os denominamos especificamente imitadores da vida virtuosa. Não são homens bons, mas se comportam como tais. Ora, o cristão em seus pensamentos, em suas palavras, e em suas ações, manifesta sua intenção muito sagrada de obedecer a Deus, o que é bem mais do que aquilo com o que a maioria dos filósofos concorda, ó $\mu о \lambda o \gamma o v \mu \varepsilon ́ v \omega \varsigma$ $\tau \eta \varphi v ́ \sigma \varepsilon \imath \zeta \eta v$, viver de acordo com a natureza. ${ }^{137}$

Mas porque muito frequentemente a fraqueza humana - que ainda não triunfou sobre os outros vícios - tropeça face às regras, às proibições e aos mandamentos, vem uma regra tomar o lugar de todas as outras: ser movido pelo arrependimento e pedir perdão. A razão dessa regra foi longamente exposta quando eu tratei dos princípios. ${ }^{138}$

Depois de ter tratado das regras, vale a pena considerar o quanto nosso mundo deve à religião cristã. Outrora, a maioria dos povos era constituída de bárbaros, selvagens, incultos, $\chi \varepsilon \imath \rho o \delta i ́ k \alpha l$, (submetidos à lei da forca); eles receberam desse ensinamento [cristão] a moral e o direito. Ainda mais, alguns povos que se consideravam perfeitamente humanos expunham suas crianças, antes da instituição do cristianismo, e se alegravam em publico com o espetáculo do sangue humano. Essa discriminação entre os homens, oriunda da força que envergonha a natureza, - que faz com que alguns sejam livres e outros escravos - não desapareceu da vida por um movimento violento, mas pouco a pouco, graças à equidade cristã. Não há necessidade de leis e castigos para forçar ao casamento pessoas que não o querem, mas, uma vez suprimida a licença libidinosa, os homens se casam de sua plena vontade e engendram uma descendência - que é suficiente para a cidade - não como antes, por uniões descompromissadas, mas numa fidelidade sólida e indivisa. Por isso, se a vida cristã correspondesse a seu nome, sem guerra, sem conflitos, sem miséria, na maior paz, concórdia e abundância de coisas indispensáveis a cada um, tratar-se-ia realmente da idade de ouro.

Quando o último ancião muito santo expôs integralmente o corpus da religião cristã, ele disse que era surpreendente que as pessoas que estão de acordo sobre coisas tão importantes pareçam, entretanto, ser tão diferentes e discordantes. Procurando a causa desse mal, parece-me, diz ele,

\footnotetext{
${ }^{136}$ Sêneca, De beneficiis, V, 14, 2.

${ }^{137}$ Definição estoica da virtude, Cf. Diógenes Laercio, VII, 88.

${ }^{138}$ Cf. inclusive $\$ 43 \& 70$.
}

Hugo Grotius - Meletius ou carta sobre aquilo que é objeto de acordo entre os cristãos. Tradução por Weslin de Jesus Santos Castro. Revisão por Dominique Marie Phillipe Geneviève Boxus 
que ela se deve, sobretudo, por isso: pretende-se que os princípios teóricos constituam a parte mais importante da religião e relegam-se as regras práticas ao segundo lugar. Ora, isto é evidentemente falso, porque os princípios estão ordinariamente ao serviço das regras práticas e para estas conduzem. Portanto, é bem verdade o que diz Sêneca que todos "preferem mais disputar a viver". ${ }^{139}$ Posto que as regras práticas sejam geralmente mais claras e menos confusas, o acordo é máximo sobre regras. Mas nós preferimos nos deter nos princípios teóricos porque nesses nos disputamos com outrem, e nas regras com nós mesmos, de maneira que é mais difícil ser violento consigo mesmo que se bater com alguém. $O$ homem não gosta muito de cumprir seu dever, por isso ele transformou a religião em controvérsia, e o que era próprio da escola, ele transportou para a vida.

Quando não há um conflito sobre as regras práticas, isso não concerne geralmente aos costumes, porque são regras constantes e manifestas, mas ao que cada um estabelece para si mesmo a fim de preservar a ordem; nesse ponto o caminho da concórdia é curto: permitir a cada um fazer o que julga ser bom. O que é mais estúpido que as ações dos espartanos e atenienses, levando a guerra pelas cidades gregas, uns para transferir tudo para o comando do povo, outros para o governo dos melhores. Há muitas coisas parecidas entre os cristãos. Quão grandes as dissensões que nasceram outrora porque não se celebrava a Páscoa no mesmo dia! Irene escreveu com sabedoria para o bispo de Roma, Victor: E então? Não podemos viver harmoniosamente, ainda que uns sigam seus ritos e nós os nossos? Para a quaresma, uns jejuam dois dias, outros quatro dias, outros dez, quinze, vinte, quarenta dias, no entanto, a concórdia é mantida. Nos princípios, muitas controvérsias ficam no plano das palavras, se as evitarmos o acordo aparece. Se o conflito subsiste, vejamos se ele não traz coisas que não são absolutamente necessárias para saber. $O$ erro que é preciso corrigir primeiramente é que os princípios são geralmente mais numerosos do que é pedido pela prática das regras. Não é possível fazer com que todos estejam de acordo acerca de todas as questões. Cada um se detém obstinadamente naquilo que uma vez aprendeu mesmo se for falso. Aquilo que eles aprenderam quando jovens, "os anciãos não querem admitir que lhes é necessário esquecer." ${ }^{140}$ Outrossim “como afirma Galião, é uma mal tão difícil de ser retirado quanto o amor ciumento por sua seita e é de todas as coisas o que se pode menos apagar, um mal bem mais incurável que a sarna." $" 141$

\footnotetext{
${ }^{139}$ Referência não consta no texto original. (N.T.)

140 "les vieux ne veulent pas admettre qu'il le leur faut oublier." (Horácio Ep. II, 1, 85.)

141 "Comme le dit Galien 'c'est un mal si difficile à ôter que l'amour jaloux pour sa secte et c'est de toutes choses ce qu'on peut le moins effacer, mal bien plus incurable que la gale". (Galião: De naturalibus facultatibus, I, 34).
}

Hugo Grotius - Meletius ou carta sobre aquilo que é objeto de acordo entre os cristãos. Tradução por Weslin de Jesus Santos Castro. Revisão por Dominique Marie Phillipe Geneviève Boxus 
O remédio para essa doença será então reduzir o número de coisas necessárias a acreditar a um pequeno numero de artigos muito evidentes; para os outros que se voltam para a perfeição da sabedoria piedosa, o remédio é encontrar esses artigos nos estudos à parte, preservando a caridade e sob a guia de livros sagrados. Em seguida, se alguns erram, mesmo sobre coisas de alguma importância, não nos cabe perseguir com uma acusação odiosa aqueles que um erro subjuga, mas apagar com uma explicação benevolente a infelicidade de sua ignorância. Se nós devemos perdoar os pecados cometidos contra as regras conhecidas e compreendidas, o quanto mais o devemos com o erro que alguém assume sem o ter querido.

Há uma opinião bem digna de memória de Salvião sobre esse assunto, um texto no qual ele trata do erro mais abominável do seu tempo, e essas palavras concluirão bem meu discurso:

Logo, eles são hereges, mas sem sabê-lo. Dessa forma, eles são hereges para nós, não para eles. Eles acreditam tanto ser católicos que eles nos ultrajam, com a apelação infame de hereges. E, portanto, o que eles são para nós, nós o somos para eles. A verdade está conosco, mas eles pensam que está com eles. A honra de Deus está conosco, mas eles estimam que a honra divina é aquilo em que eles creem. Eles faltam com seus deveres, mas é aí para eles o dever supremo da religião. Eles são ímpios, mas acreditam que aí é a verdadeira piedade. Logo, eles erram, mas, de boa-fé, não por ódio, mas por amor a Deus, acreditando honrar a Deus e amá-lo. Ainda que eles não tenham a fé correta, eles estimam, entretanto que é o perfeito amor de Deus. Qualquer que seja a maneira por meio da qual eles devam ser punidos no dia do juízo - por esse erro preciso de uma opinião falsa - ninguém pode sabê-lo senão o Juiz. Esperando por isso, conforme o que acho, Deus recomenda a paciência para com eles, porque ele vê que mesmo se sua crença não for correta, eles erram com o sentimento de uma opinião pia." ${ }^{142}$

\footnotetext{
142 "Ils sont donc hérétiques, mais sans le savoir. Aussi sont-ils hérétiques pour nous, non pour eux. Ils pensent tellement être catholiques qu'ils nous affublent nous, de l'appelation infamante d'hérétiques. Et donc ce qu'ils sont pour nous, nous le sommes pour eux. [...] La vérité est de notre côté, mais eux pensent qu'elle est du leur. L'honneur de Dieu est avec nous, mais eux estiment que l'honneur de la divinité est ce qu'ils croient. Ils manquent à leurs devoirs mais c'est là pour eux le devoir supreme de la religion. Ils sont impies mais croient que la est la vraie piété. Ils errent donc mais de bonne foi, non par haine mais par amour de Dieu, croyant honorer Dieu et l'aimer. Bien qu'ils n'aient pas la foi droite, eux estiment cependant, que c'est le parfait amour de Dieu. Quelle sera la façon dont ils devront être punis le jour du jugement pour cette erreur précise d'une opinion fausse, nul ne peut le savoir sinon le Juge. En attendant Dieu, à ce que je crois, recomande la patience envers eux, parce qu'il voit que même si leur croyance n'est pas correcte, ils errent avec le sentiment d'une opinion pieuse."

Hugo Grotius - Meletius ou carta sobre aquilo que é objeto de acordo entre os cristãos. Tradução por Weslin de Jesus Santos Castro. Revisão por Dominique Marie Phillipe Geneviève Boxus
} 